Canadian

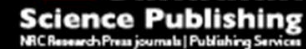

Canadian Journal of Chemistry Revue canadienne de chimie

\title{
Synthesis and evaluation of original bioisosteres of bacterial type IIA topoisomerases inhibitors
}

\begin{tabular}{|c|c|}
\hline Journal: & Canadian Journal of Chemistry \\
\hline Manuscript ID & cjc-2015-0475.R1 \\
\hline Manuscript Type: & Article \\
\hline Date Submitted by the Author: & 04-Nov-2015 \\
\hline Complete List of Authors: & $\begin{array}{l}\text { Petrella, Stéphanie; Institut Pasteur } \\
\text { Aubry, Alexandra; Faculté de Médecine Pierre et Marie Curie } \\
\text { Janvier, Geneviève; Institut Pasteur } \\
\text { Coutant, Eloi; Institut Pasteur } \\
\text { Cartier, Alex; Institut Pasteur } \\
\text { Dao, Thuy-Ha; Institut Pasteur } \\
\text { Bonhomme, Frédéric; Institut Pasteur } \\
\text { Motreff, Laurence; Institut Pasteur } \\
\text { Pissis, Cédric; Institut Pasteur } \\
\text { Bizet, Chantal; Institut Pasteur } \\
\text { Clermont, Dominique; Institut Pasteur } \\
\text { Begaud, Evelyne; Institut Pasteur } \\
\text { Retailleau, Pascal; Institut de Chimie des Substances Naturelles } \\
\text { Munier-Lehmann, Hélène; Insitut Pasteur } \\
\text { Capton, Estelle; Faculté de Médecine Pierre et Marie Curie } \\
\text { Mayer, Claudine; Institut Pasteur } \\
\text { Janin, Yves; Institut Pasteur, Biologie Structurale et Chimie }\end{array}$ \\
\hline Keyword: & ATPase, topoisomerases, antibiotic, bioisosteres, pyrazole \\
\hline
\end{tabular}




\section{Synthesis and evaluation of original bioisosteres of bacterial type IIA topoisomerases inhibitors}

Stéphanie Petrella, ${ }^{\text {abc }}$ Alexandra Aubry, ${ }^{\text {def }}$ Geneviève Janvier, ${ }^{\text {ab }}$ Eloi P. Coutant, ${ }^{\text {gh }}$ Alex Cartier, ${ }^{\text {gh }}$ Thuy-Ha Dao, ${ }^{\text {gh }}$ Frédéric J. Bonhomme, ${ }^{\text {gh }}$ Laurence Motreff, ${ }^{\mathrm{i}}$ Cédric Pissis, ${ }^{\mathrm{ab}}$ Chantal Bizet, ${ }^{\mathrm{i}}$ Dominique Clermont, ${ }^{\mathrm{i}}$ Evelyne Begaud, ${ }^{\mathrm{i}}$ Pascal Retailleau, ${ }^{\mathrm{j}}$ Hélène MunierLehmann, ${ }^{\text {gh }}$ Estelle Capton, ${ }^{\text {def }}$ Claudine Mayer, ${ }^{\text {abc }}$ Yves L. Janin ${ }^{\text {gh* }}$

a: Institut Pasteur, Unité de Microbiologie Structurale, Département de Biologie Structurale et Chimie, 25 rue du Dr Roux, 75724 Paris cedex 15, France.

b: Unité Mixte de Recherche 3528, Centre National de la Recherche Scientifique, 25 rue du Dr Roux, 75724 Paris cedex 15, France.

c: Université Paris Diderot, Sorbonne Paris Cité, 25 rue du Dr Roux, 75724 Paris cedex 15, France.

d: Sorbonne Universités, Université Pierre et Marie Curie Paris 06, CR7, Centre

d'Immunologie et des Maladies Infectieuses, CIMI, team E13 (Bacteriology), 47-83 bd de l'Hôpital, 75651 Paris cedex 13, France.

e: INSERM, U1135, Centre d'Immunologie et des Maladies Infectieuses, CIMI, team E13 (Bacteriology), 47-83 bd de l'Hôpital, 75651 Paris cedex 13, France.

f: AP-HP, Hôpital Pitié-Salpêtrière, Centre National de Référence des Mycobactéries et de la Résistance des Mycobactéries aux Antituberculeux, Bactériologie-Hygiène, 47-83 bd de l'Hôpital, 75651 Paris cedex 13, France.

g: Unité de Chimie et Biocatalyse, Département de Biologie Structurale et Chimie, Institut Pasteur, 28 rue du Dr Roux, 75724 Paris Cedex 15, France. 
h: Unité Mixte de Recherche 3523, Centre National de la Recherche Scientifique, 28 rue du Dr Roux, 75724 Paris Cedex 15, France.

i: Institut Pasteur, CRBIP (Centre de Ressources Biologiques de l'Institut Pasteur), Dept Microbiologie, 25 rue du Dr Roux, 75724 Paris cedex 15, France.

j: Service de Cristallochimie, Centre de Recherche de Gif, Institut de Chimie des Substances

Naturelles, 1 avenue de la Terrasse, F-91198 Gif-sur-Yvette cedex, France

yves.janin@pasteur.fr ; tel : 33 (0)1 40613992 ; fax : 33 (0)1 45688404

keywords: bacterial type IIA topoisomerases; bioisosteres; 3-pyrazole carboxylic acid 


\begin{abstract}
A recently discovered series of inhibitors of the ATPase function of bacterial type IIA topoisomerases featuring a carboxypyrrole component led us to attempt to replace this group with a potentially bioisosteric carboxypyrazole. Accordingly, synthetic pathways to 2-(4-(1Hpyrazole-5-carboxamido)piperidin-1-yl)thiazole-5-carboxylic acids or 2-(4-(N-methyl-1Hpyrazole-5-carboxamido)piperidin-1-yl)thiazole-5-carboxylic acids featuring an array of substituents on the pyrazole ring were explored. Unfortunately, none of the analogues made were effective on the ATPase function of Mycobacterium tuberculosis gyrase, as well on the DNA supercoiling activity of the whole gyrase of M. tuberculosis and Escherichia coli. However, this work is still providing original insights in chemistry as well as in the structureactivity relationships of this series of inhibitors.
\end{abstract}

\title{
Résumé
}

Une série récente d'inhibiteurs de la fonction ATP-asique des topoisomerases bactériennes de type IIA comportant un noyau carboxypyrrole nous a conduits à tenter de remplacer celui-ci par un noyau carboxypyrazole bioisostère. Ainsi, des accès aux dérivés d'acide 2-(4-(1Hpyrazole-5-carboxamido)piperidin-1-yl)thiazole-5-carboxylique, comportant une gamme de substituants, ont été explorés. Malheureusement, aucun des analogues préparés n'a eu d'effet, que ce soit sur la fonction ATP-asique de la gyrase de Mycobacterium tuberculosis ou sur l'activité de surenroulement des gyrases de M. tuberculosis ou d'Escherichia coli. Toutefois, ce travail représente une contribution originale en ce qui concerne la chimie ou les relations structure-activité de cette série d'inhibiteurs.

Keywords: ATPase, topoisomerases; antibiotic; bioisosteres; pyrazole 


\section{Introduction}

In the recent past, the strategies used to find new antibiotics effective on bacterial strains such as multiple resistant Mycobacterium tuberculosis, the Gram-positive methicillin-resistant strains of Staphylococcus aureus (MRSA), and the vancomycin-resistant Enterococcus spp as well as the Gram-negative Actinobacter or Pseudomonas spp. currently plaguing hospitals ${ }^{1}$ have undergone many changes. A remarkable report from a major actor in the domain, reviewing the results of a full genomic approach, led amongst other conclusions to the following statement: "The only way to overcome the challenges of multifactorial antibacterial lead optimization is to expand the number of chemical derivatives. We now employ roughly two chemists for each biologist in the antibacterial therapeutic area, a fourfold turn-around from the days when genomics dominated our activities". ${ }^{2}$ The consequence of this has indeed led to extensive medicinal chemistry in the recent past, which notably led to the discovery of many original series of antibiotics inhibiting bacterial type IIA topoisomerases. ${ }^{3}$ Amongst these, series of pyrrole-containing inhibitors of the ATPase function of bacterial type IIA topoisomerases such as the compounds 1a-c depicted in figure 1 were reported. ${ }^{4,5}$ Extensive structure-activity studies led to many analogues including the pyrrolo[2,3-c]pyridine derivative $2^{6}$ or the more elaborated triazole-bearing analogue 3 . $^{7}$ The latter two were actually studied for their antimycobacterial effect on a mice model of $M$. tuberculosis infection. ${ }^{8}$ Replacing the carboxypyrrole by a carboxyimidazole group turned out to be possible and imidazole derivatives such as $\mathbf{4}$ were also claimed for their inhibition of DNA gyrase and topoisomerase IV as well as their antibacterial effect. ${ }^{9,10}$ Aside from extensive rescaffolding of the central 4-aminopiperidine with other cyclic amines, ${ }^{11-16}$ the 2-(piperidin-1-yl)thiazole component could be replaced, with relative success, by a carboxamide ${ }^{17}$ or other heterocycles ${ }^{18}$ such as the randomly chosen 4-phenyltriazole $\mathbf{5}^{19}$ and more recently, antibacterials such as the tetrahydrobenzo[1,2- $d]$ thiazole 6 were reported. ${ }^{20}$ Extensive work 
on the carboxylic acid-bearing component of these series led to compound 7 which featured an improved antibacterial activity as well as a lower in vivo clearances and was thus selected for clinical trials. ${ }^{21}$ In view of this, along with our simple method for the preparation of carboxypyrazoles, ${ }^{22}$ we set to prepare the pyrazole-bearing series of compounds $\mathbf{8}$ and $\mathbf{9}$ in order to determine in this case whether a pyrazole nucleus could also be a bioisostere of the carboxy-pyrrole component.

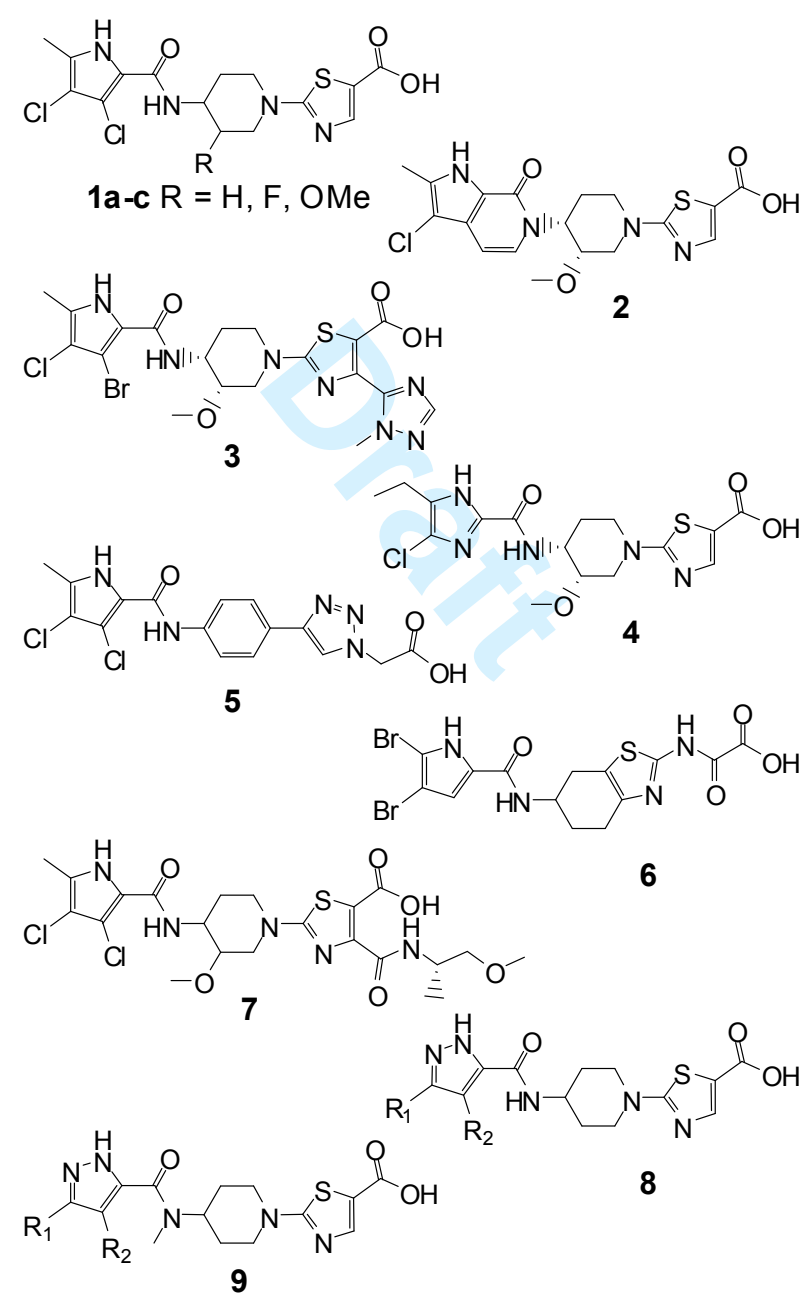

Figure 1. Structures of compounds 1-9.

\section{Results and discussion}


As depicted in scheme 1, the pyrazole acids 11a-d were obtained by hydrolysis of the corresponding trifluoromethyl pyrazoles $\mathbf{1 0 a - d}$, as previously reported ${ }^{22}$ or described in the experimental part. Initially, their coupling with the dihydrochloride salt of amine 12, previously described, ${ }^{23}$ to give amides 13a-d was achieved using a mixture of phosphorus oxychloride and pyridine. This unusual method has been successfully applied in the past for difficult cases $^{24}$ including one involving a pyrazole carboxylic acid. ${ }^{25}$ However, if the modest yield obtained could be raised with an excess of the acid and phosphorus oxychloride in some cases we realized later on in the course of the preparation of the $\mathrm{N}$-methyl derivatives 9 that $O$-(benzotriazol-1-yl)- $N, N, N^{\prime}, N^{\prime}$-tetramethyluronium tetrafluoroborate (TBTU) was a far better coupling agent. To prepare the trifluoromethyl bearing amide $13 \mathbf{e}$, we used the $\mathrm{N}$ protected acid 14 (preparation described in the experimental part). Coupling of this acid with amine 12 using phosphorus oxychloride and pyridine followed by the cleavage of the ethoxyethyl protecting group gave compound $13 \mathbf{e}$ in an $18 \%$ overall yield. Hydrolysis of esters 13a-e to give the target acids 8a-e was achieved using lithium hydroxide as described for the pyrrole series of inhibitors. ${ }^{23}$ A relatively large scale $(200 \mathrm{mg})$ and a minimal amount of water were found necessary to isolate, by precipitation, substantial amount of the rather water-soluble acids $\mathbf{8 a}$ and $\mathbf{8 b}$. Unfortunately, a complete lack of inhibition effect was observed for the analogues 8a-e on disk-based assays for bacterial strains such as E. coli (data not shown). Moreover, to remove the possibility of a lack of membrane solubility which would have explained these results, compounds 8a-e were also assessed on various bacterial gyrases assays. No effect was seen on the DNA supercoiling activity of the whole DNA gyrases of M. tuberculosis and E. coli, even at the highest concentration tested (2.5 mM; data not shown). 

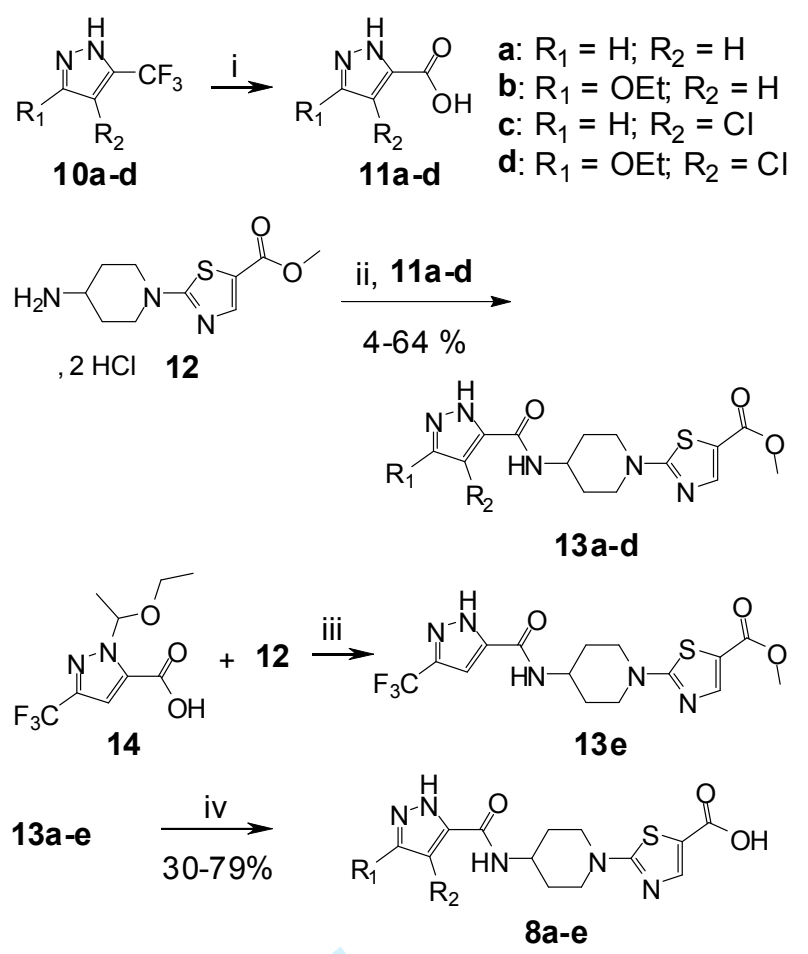

Scheme 1: i: $\mathrm{NaOH}, \mathrm{EtOH} / \mathrm{H}_{2} \mathrm{O}$, mw $150{ }^{\circ} \mathrm{C}$. ii: $\mathrm{POCl}_{3}$, pyridine. iii: a) $\mathrm{POCl}_{3}$, pyridine, b) $\mathrm{H}_{3} \mathrm{O}^{+} \mathrm{Cl}^{-}$, EtOH. iv: $\mathrm{LiOH}, \mathrm{THF} / \mathrm{H}_{2} \mathrm{O}$.

For the synthesis of the N-methylated analogues $\mathbf{9 a - j}$, a different synthetic approach to the key intermediate 19 was initially explored. By heating equimolar amount of the $\mathrm{N}$ methylpyridin-4-amine (15) and the methyl 2-bromothiazole-5-carboxylate (16) in a microwave oven at $100{ }^{\circ} \mathrm{C}$ for 15 minutes, a close to quantitative yield of the pyridinium salt 17 was obtained. Treatment of this salt with sodium borohydride in methanol led to a mixture of the partially hydrogenated dihydropyridine $\mathbf{1 8}$ and a smaller proportion of the target piperidine 19, which could not be separated at this stage. Reduction trials with various borohydrides did not improve this ratio nor atmospheric palladium-catalyzed hydrogenation of the mixture of $\mathbf{1 8}$ and 19. In any case, the coupling of these crude amines with pyrazole carboxylic acids 11a-c, using the much more efficient TBTU, gave a mixture of the amides 20a-c and 21a-c from which the pure 3,4-dihydropyridines 20a-c could be isolated in 30-49 
$\%$ yield. The LC/MS monitoring of this reaction actually pointed out the occurrence of various pairs of TBTU adducts (i.e.: $m / z=446$ and 448 or $m / z=419$ and 421 , when coupling the mixture of $\mathbf{1 8}$ and $\mathbf{1 9}$ with acid 11a). This led us to add ammonia in the reaction mixture to decompose them before the reaction work up. The reduction of the dihydropyridine ring of amides 20a-c turned out to be challenging and the only reagents which provided modest amount of the reduced compounds 21a-c (22-45\% yield) was the combination of triethylsilane and trifluoromethane sulfonic acid. Extensive investigation of the various products arising from this ionic-based reduction was made and in the case of compound $\mathbf{2 0 b}$, we could isolated the tricyclic derivative 22. As described below, the bridged structure of this compound was fully established by an X-ray crystallography study. The mechanism for the occurrence of this compound is quite straightforward, upon protonation of the 3,4dihydropyridine double bond of compound $\mathbf{2 0 b}$, the resulting cation can either be quenched by the triethylsilane, to give the reduced amide $\mathbf{2 1 b}$, or react internally with the nucleophilic nitrogen of the pyrazole ring to give 22. Hydrolysis of the methyl ester of compounds 21a-c, to give the target analogues 9a-c, was then achieved as above using lithium hydroxide. Concerning the ${ }^{1} \mathrm{H}$ NMR characterization of all these $N$-methylamides, their ${ }^{1} \mathrm{H}$ NMR spectra at room temperature pointed out the occurrence of equilibrium between at least two conformations. In every cases, as described in the experimental part, when raising the temperature to $90{ }^{\circ} \mathrm{C}$, all the ${ }^{1} \mathrm{H}$ NMR signals resolved into a single conformation much easier to describe. For the same reason, the ${ }^{13} \mathrm{C}$ NMR spectra obtained at room temperature were intractable and no attempts were made to obtain them at $90{ }^{\circ} \mathrm{C}$. 

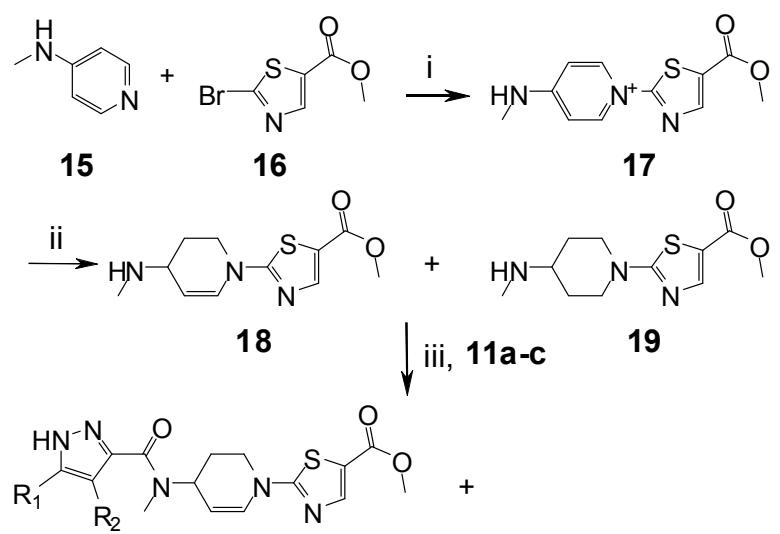

$20 \mathrm{a}-\mathrm{c}(30-49 \%)$

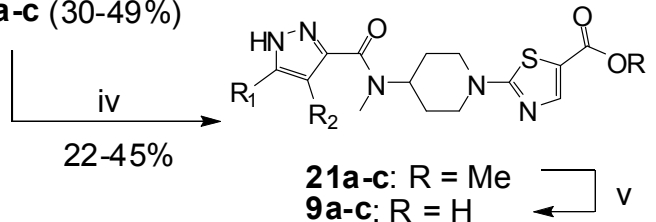
a: $R_{1}=H ; R_{2}=H$
b: $\mathrm{R}_{1}=\mathrm{OEt} ; \mathrm{R}_{2}=\mathrm{H}$
c: $\mathrm{R}_{1}=\mathrm{H} ; \mathrm{R}_{2}=\mathrm{Cl}$

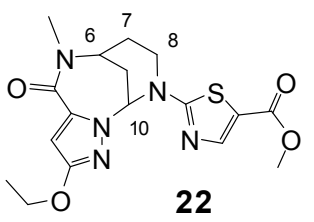

Scheme 2: i: $\mathrm{MeCN}, 100{ }^{\circ} \mathrm{C}, 15 \mathrm{mn}$. ii: $\mathrm{NaBH}_{4}, \mathrm{MeOH}$. iii: a)TBTU, $\operatorname{Pr}_{2} \mathrm{EtN}, \mathrm{THF}, 2{ }^{\circ} \mathrm{C}, \mathrm{b}$ ) $\mathrm{NH}_{4} \mathrm{OH}$. iv: $\mathrm{Et}_{3} \mathrm{SiH}, \mathrm{CF}_{3} \mathrm{SO}_{3} \mathrm{H}, \mathrm{CH}_{2} \mathrm{Cl}_{2}, 20^{\circ} \mathrm{C}, 12 \mathrm{~h}$. v: $\mathrm{LiOH}, \mathrm{MeOH}, \mathrm{H}_{2} \mathrm{O}, 20{ }^{\circ} \mathrm{C}, 12 \mathrm{~h}$.

The Ortep-3 diagram ${ }^{26}$ of compound 22 is shown in Figure 2. The crystallographic data collection and refinement parameters are in table 1 in the experimental part. Compound 22 crystallizes in the triclinic space group $\mathrm{P}-1$, with one molecule in the asymmetric unit. A geometric analysis of all bond distances and angles performed by carrying out a Mogul ${ }^{27}$ geometry check implemented in the program Mercury ${ }^{28}$ showed that most bond distances, bond angles and torsion angles have typical geometry. Only a couple of valence angles (C2_C1_N1 and O4-C2-C1) concerning the pyrazolo-diazepanone bicycle have an absolute value of z-score slightly above 4 . Two planes may be defined through the heteroatom skeleton of the molecule. Plane 1 is formed by the pyrazole ring fused with diazepane ring, which adopts a sofa conformation since the $\mathrm{C} 4$ is the most distant atom from the mean plane of the ring $(0.775(2) \AA)$. Plane 2 is formed by the piperidine ring to which is attached, equatorially at 
the N3 atom, the thiazole ring. Cremer and Pople ring puckering parameters ${ }^{29}(\mathrm{Q}=0.517(2)$ $\left.\AA, \theta=176.9(2)^{\circ}, \varphi=120(5)^{\circ}\right)$ suggest that the piperidine ring is in a chair conformation. The dihedral angle between the two planes is $75.7^{\circ}$.

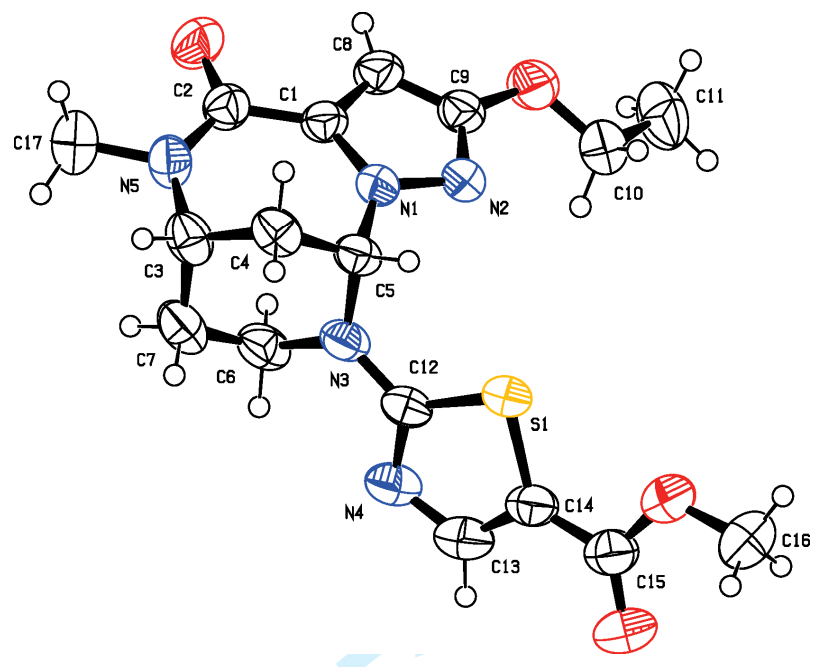

Figure 2. X-ray based structure of compound 22.

To avoid the difficulties encountered in the reduction of compounds $\mathbf{2 0 a - c}$, the alternative pathway, depicted in scheme 3, was investigated for the preparation of analogues $9 \mathbf{d}-\mathbf{j}$. As observed by LC/MS, the condensation of $N$-methylpiperidin-4-amine (20) with the 2bromothiazole $\mathbf{1 3}$ led to a mixture of the double and mono-substituted products 21 and $\mathbf{1 6}$. To confirm the reported ${ }^{30}$ regioselectivity of such $\mathrm{N}$-arylation step in our case, the coupling of the crude mixture of $\mathbf{2 1}$ and $\mathbf{1 6}$ was first undertaken with the 4-chloropyrazole-5-carboxylic acid (8c). In this control experiment, amide 18c was thus obtained in a $9 \%$ overall yield from the piperidine 20. Despite this rather low yield, because of the simplicity of this pathway, the amides 18d-j were then prepared from the corresponding carboxypyrazoles $\mathbf{8 d} \mathbf{d}-\mathbf{j}$ (preparations described in the experimental part). From these esters, their hydrolysis, using lithium hydroxide, gave the target acids $\mathbf{9 d - j}$ in 46-75 \% yield. Two types of biochemical assays were 
performed: DNA supercoiling and ATPase activity inhibitions. A very weak inhibition was observed using the DNA supercoiling assays (M. tuberculosis as well as E. coli) for compound $9 \mathbf{b}\left(\mathrm{IC}_{50}=2 \mathrm{mM}\right)$ in which moxifloxacin displayed an $\mathrm{IC}_{50}$ of $2.5 \mu \mathrm{M}$ but no effect was observed on the ATPase activity. Unfortunately none of the analogues subsequently made had any effect on these two types of biochemical assays.

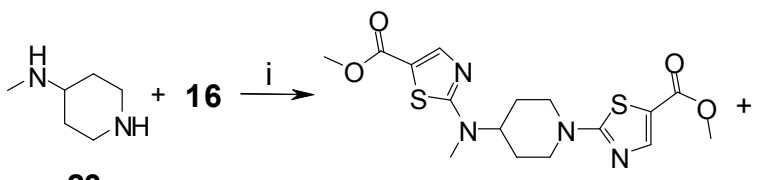

23

24
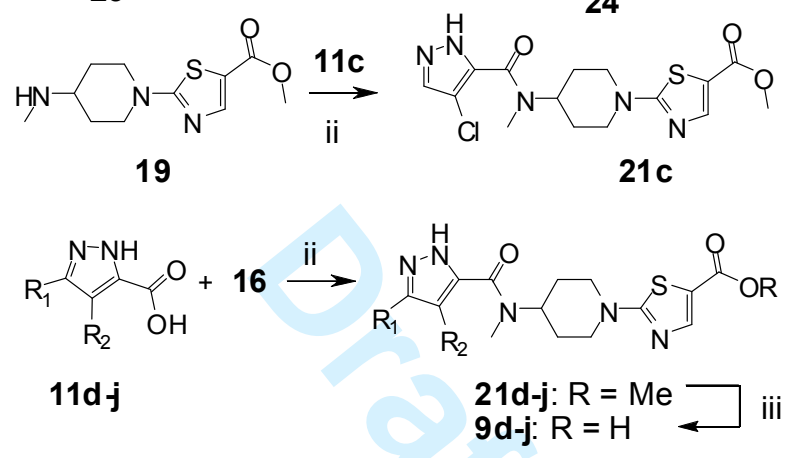
d: $\mathrm{R}_{1}=\mathrm{OEt}, \mathrm{R}_{2}=\mathrm{Cl}$
e: $R_{1}=O P r, R_{2}=H$
f: $R_{1}=O B u, R_{2}=H$
g: $\mathrm{R}_{1}=\mathrm{OiPr}, \mathrm{R}_{2}=\mathrm{H}$
h: $\mathrm{R}_{1}=\mathrm{OCH}(\mathrm{Et})_{2}, \mathrm{R}_{2}=\mathrm{H}$
i: $\mathrm{R}_{1}=\mathrm{CH}_{3}, \mathrm{R}_{2}=\mathrm{Br}$
$\mathrm{j}: \mathrm{R}_{1}=\mathrm{CF}_{3}, \mathrm{R}_{2}=\mathrm{Br}$

Scheme 3: i: $i_{2}{ }_{2} E t N, M e C N, 100{ }^{\circ} \mathrm{C}, 2 \mathrm{~h}, \mathrm{MW}$. ii: a) $\left.\mathrm{TBTU}, \mathrm{iPr}_{2} \mathrm{EtN}, \mathrm{THF}, 20{ }^{\circ} \mathrm{C}, \mathrm{b}\right)$

$\mathrm{NH}_{4} \mathrm{OH}$. iii: $\mathrm{LiOH}, \mathrm{MeOH}, \mathrm{H}_{2} \mathrm{O}, 20^{\circ} \mathrm{C}, 12 \mathrm{~h}$.

\section{Conclusion}

This work was an attempt to determine whether a carboxypyrazole could, in the present case, be a bioisosteric replacement of a carboxypyrrole. On the chemistry point of view, by using the previously disclosed synthesis of compound $\mathbf{1 2},{ }^{23}$ we could couple it with various pyrazole carboxylic acids and this led to the analogues 8a-e. To synthesize the $N$-methylated derivatives 9a-j, two synthetic pathways were investigated. The first one used an original access to compound $\mathbf{1 8}$ and allowed the preparation of analogues 9a-c. However, this path 
features the drawback of a side reaction leading to bridged products such as the fully identified compound 22. To avoid this, a second path was sought and we first established that equimolar reaction between the $N$-methylated piperidine 23 and the 2-bromothiazole 16 does provide an access to the key $N$-methyl intermediate 19 along with the bis-substituted compound 24. This path was used to prepare analogues $9 \mathbf{d}-\mathbf{j}$ which, in view of the lipophilic group of most active pyrrole-bearing series depicted in figure 1, were dressed with various combination of lipophilic groups on their pyrazole ring. However, the effect of compounds 9a-j on the whole DNA gyrases assays of M. tuberculosis and E. coli turned out to be disappointing. In this regard, the replacement of the lipophilic methyl group of the pyrrolebearing antibacterials depicted in figure 1 by a polar nitrogen atom is indeed not favorable. Despite this, we hope that this report, which provides some insights in the chemistry of these series as well as in their structure-activity relationships, will still be useful to other investigators.

\section{Experimental part}

Disk-based assays. The strain used in this study was E. coli CIP 76.24 (susceptible to ofloxacin). For routine use, this strain was grown at $37^{\circ} \mathrm{C}$ on trypticase soy agar plates (BioMérieux, La Balme-Les-Grottes, France). The antimicrobial susceptibility test was performed on Mueller-Hinton agar (BioMérieux, La Balme-Les-Grottes, France) by an agar diffusion method, according to the guidelines of the Antibiogram Committee of the French Society for Microbiology. ${ }^{31}$ Each compound was solubilized in DMSO to obtain a solution of $50 \mathrm{mg} / \mathrm{ml}$. The in vitro susceptibility to 5 compounds was tested by the agar dilution method. These solubilized compounds were used immediately after dilution. The serial dilutions were performed in physiological serum and $10 \mu \mathrm{L}$ of the dilution were deposited on a blank disk (Biorad). A disk without any compound, and another with $10 \mu \mathrm{l}$ DMSO were added on the 
plates, as negative controls. All plates were incubated at $37^{\circ} \mathrm{C}$ for $24 \mathrm{~h}$. The strain was fully impervious to the compounds 5a-e tested.

DNA supercoiling assay. The $M$. tuberculosis DNA gyrase was purified as described previously. ${ }^{32}$ The reaction mixture (total volume, $30 \mu$ l) contained DNA gyrase assay buffer (40 mM Tris- $\mathrm{HCl}$ [pH 7.5], $25 \mathrm{mM} \mathrm{KCl,} 6 \mathrm{mM}$ magnesium acetate, $2 \mathrm{mM}$ spermidine, $4 \mathrm{mM}$ dithiothreitol, bovine serum albumin $[0.36 \mu \mathrm{g} / \mathrm{mL}], 10 \mathrm{mM}$ potassium glutamate, $1 \mathrm{mM}$ ATP [pH 8.0]) and relaxed pBR322 DNA $(0.4 \mu \mathrm{g})$ as the substrate. Gyrase proteins (180 ng of GyrA and $126 \mathrm{ng}$ of GyrB) were mixed in the presence of increasing concentrations of quinolones for $1 \mathrm{~h}$ at $37^{\circ} \mathrm{C}$. Reactions were terminated by the addition of $50 \%$ glycerol containing $0.25 \%$ bromophenol blue, and the total reaction mixture was subjected to electrophoresis in a $1 \%$ agarose gel in 0.5X TBE (Tris-borate- EDTA, pH 8.3) buffer. After electrophoresis for $5.5 \mathrm{~h}$ at $50 \mathrm{~V}$, the gel was stained with ethidium bromide $(0.7 \mu \mathrm{g} / \mathrm{mL})$. The inhibitory effect of quinolones on DNA gyrase was assessed by determining the concentration of drug required to inhibit the supercoiling activity of the enzyme by $50 \%$ (IC50). Supercoiling activity was assessed by tracing the brightness of the bands corresponding to the supercoiled pBR322 DNA with Molecular Analyst software (Bio-Rad). For the E. coli DNA gyrase assay, a similar protocol was used with a commercial available (John Innes Enterprises Ltd) recombinant enzyme.

DNA gyrase ATPase assay. The M. tuberculosis DNA gyrase ATPase domain was purified as described previously. ${ }^{33}$ The ADP-Glo ${ }^{\mathrm{TM}}$ kinase assay (Promega, Madison, WI) was used to test the ATPase inhibition of the compounds having $\mathrm{IC}_{50}$ values for supercoiling inhibition below or equal to $2 \mathrm{mM}$. The ATPase assay was carried out in a 384-well plate with a $5 \mu \mathrm{L}$ volume containing $0.7 \mu \mathrm{l}$ of $40 \mathrm{~g} / 1$ M. tuberculosis ATPase, $1 \mu \mathrm{L}$ Reaction Buffer (Tris 40 $\mathrm{mM}(\mathrm{pH}=7.5), \mathrm{MgCl}_{2} 20 \mathrm{mM}, \mathrm{KCl} 50 \mathrm{mM}$, BSA $\left.0.1 \mathrm{mg} / \mathrm{mL}\right)$ and $0.5 \mu 1$ ultra pure ATP 1 mM. Reactions in each well were started by adding the ATP solution and kept going for an 
hour at $20^{\circ} \mathrm{C}$. Then $5 \mu 1$ of ADP-Glo reagent was added into each well to stop the reaction and consume the remaining ADP within 40 minutes. At the end, $10 \mu \mathrm{L}$ of the kinase detection reagent was added into the well and incubated for 1 hour and then the luminescence was monitored. Note: the novobiocin used as a reference in this assay had an $\mathrm{IC}_{50}$ of $1 \mu \mathrm{M}$.

X-ray analysis. X-ray data were collected at $293 \mathrm{~K}$ using $\mathrm{CuK} \alpha(1.54187 \AA)$ on a Rigaku mm007 HF rotating anode diffractometer equipped with Osmic CMF mirror and a curved imaging-plate RapidII detector. The Rigaku CrystalClear-SM Expert 2.0 r15 software package $^{34}$ was used for data collection and data reduction. The data were corrected semiempirically for absorption using multi-scan approach through the Fs Process scaling algorithm. The structure was solved by direct methods using SHELXS-97 $7^{35}$ and refined by full-matrix least squares on $F^{2}$ using SHELXL-2014/7. ${ }^{36}$ All non-hydrogen atoms were successfully refined using anisotropic displacement parameters. Hydrogen atoms were found in the Fourier difference synthesis and fixed. Crystallographic data for the structure of compound 22 were deposited in the Cambridge Crystallographic Data Centre, with number CCDC 1049028.

\begin{tabular}{|c|c|}
\hline Empirical formula & $\mathrm{C}_{17} \mathrm{H}_{2} \mathrm{~N}_{5} \mathrm{O}_{4} \mathrm{~S}$ \\
\hline Formula weight & 391.45 \\
\hline Temperature & $293(2) \mathrm{K}$ \\
\hline Wavelength & $1.54187 \AA$ \\
\hline $\begin{array}{l}\text { Crystal system, Space } \\
\text { group }\end{array}$ & Triclinic, $\mathrm{P}-1$ \\
\hline Unit cell dimensions & $\begin{array}{l}\mathrm{a}=8.8695(2) \AA \\
\mathrm{a}=113.309(8)^{\circ} \\
\mathrm{b}=10.7315(3) \AA \\
\mathrm{b}=98.373(7)^{\circ} \\
\mathrm{c}=10.8733(7) \AA \\
\mathrm{g}=96.812(7)^{\circ}\end{array}$ \\
\hline Volume & $922.50(9) \AA^{3}$ \\
\hline Z, Calculated Density & $2,1.409 \mathrm{mg} / \mathrm{m}^{3}$ \\
\hline Absorption coefficient & $1.863 \mathrm{~mm}^{-1}$ \\
\hline $\mathrm{F}(000)$ & 412 \\
\hline Crystal size & $0.380 \times 0.340 \times 0.270 \mathrm{~mm}^{3}$ \\
\hline $\begin{array}{l}\text { Theta range for data } \\
\text { collection }\end{array}$ & 4.530 to $68.248^{\circ}$ \\
\hline & \\
\hline
\end{tabular}




\begin{tabular}{|c|c|}
\hline Index ranges & $\begin{array}{l}-10 \leq \mathrm{h} \leq 10,-12 \leq \mathrm{k} \leq 12 \\
-13 \leq 1 \leq 13\end{array}$ \\
\hline Reflections collected & 12730 \\
\hline Independent reflections & $3283[\mathrm{R}($ int $)=0.0301]$ \\
\hline $\begin{array}{l}\text { Completeness to theta }= \\
67.687^{\circ}\end{array}$ & $96.7 \%$ \\
\hline Absorption correction & $\begin{array}{l}\text { Semi-empirical from } \\
\text { equivalents }\end{array}$ \\
\hline $\begin{array}{l}\text { Max. and min. } \\
\text { transmission }\end{array}$ & 0.61 and 0.47 \\
\hline Refinement method & $\begin{array}{l}\text { Full-matrix least-squares } \\
\text { on } F^{2}\end{array}$ \\
\hline $\begin{array}{l}\text { Data / restraints / } \\
\text { parameters }\end{array}$ & $3262 / 0 / 247$ \\
\hline Goodness-of-fit on $F^{2}$ & 1.075 \\
\hline Final R indices $[I>2 \sigma(I)]$ & $\begin{array}{l}\mathrm{R} 1=0.0416, \\
\mathrm{wR} 2=0.1101\end{array}$ \\
\hline $\mathrm{R}$ indices (all data) & $\begin{array}{l}\mathrm{R} 1=0.0527 \\
\mathrm{wR} 2=0.1199\end{array}$ \\
\hline Largest diff. peak and hole & 0.217 and -0.174 e..$\AA^{-3}$ \\
\hline
\end{tabular}

Chemistry. A Biotage initiator 2 microwave oven was used for reactions mentioning such heating method. ${ }^{1} \mathrm{H}$ NMR and ${ }^{13} \mathrm{C}$ NMR spectra were recorded on a Bruker Avance 400 spectrometer at $400 \mathrm{MHz}$ and $100 \mathrm{MHz}$, respectively. Shifts $(\delta)$ are given in ppm with respect to the TMS signal and cross-coupling constants $(J)$ are given in hertz. Column chromatography were performed either on Merck silica gel $60(0.035-0.070 \mathrm{~mm})$ or neutral alumina using a solvent pump and an automated collecting system driven by a UV detector set to $254 \mathrm{~nm}$ unless required otherwise. Sample deposition was carried out by adsorption of the mixture to be purified on a small amount of the solid phase followed by its deposition on the top of the column. The low resolution mass spectra were obtained on an Agilent 1100 series LC/MSD system using an atmospheric electrospray ionization system and the high resolution mass spectra (HRMS) were obtained using a Waters Micromass Q-Tof with an electrospray ion source. Unless stated otherwise, a purity of at least $95 \%$ was obtained for all the compounds by means of chromatography, recrystallization or distillation and this level of purity was established by TLC, LC/MS and NMR spectroscopy. Moxifloxacin, used as active compound for the supercoiling assays, was provided by Bayer Pharma, Puteaux, France. 


\section{General procedure for the hydrolysis of trifluoromethylpyrazole into pyrazole-5-} carboxylic acid

As previously described for other cases $^{22}$ in a Biotage tube, the relevant trifluoromethylpyrazole $(1 \mathrm{mmol})$ and sodium hydroxide $(0.2 \mathrm{~g}, 5 \mathrm{mmol})$ were stirred in ethanol/water $1: 3(1.2 \mathrm{~mL})$. The tube was sealed and heated at $150{ }^{\circ} \mathrm{C}$ for $1 \mathrm{~h}$ in a microwave oven. The resulting suspension was dissolved in water; the aqueous phase was washed with dichloromethane twice and made acidic with $2 \mathrm{~N}$ hydrochloric acid. This was extracted with ethyl acetate twice; the organic layer were combined and washed with brine, dried over magnesium sulfate, and concentrated to dryness to yield the corresponding acid as described below. CAUTION: the reaction leads to the release of fluorine ions which attack the glass tubes. Never recycle the reaction tubes as their resistance toward pressure and temperature may have been weakened in the process.

4-Chloro-3-ethoxy-1H-pyrazole-5-carboxylic acid (11d): Step 1, preparation of 4-chloro-3ethoxy-5-(trifluoromethyl)-1H-pyrazole (10d): In ethanol $(50 \mathrm{~mL})$, 3-ethoxy-5(trifluoromethyl)-1H-pyrazole (1.42 g, $7.89 \mathrm{mmol})^{37}$ and $N$-chlorosuccinimide $(1.26 \mathrm{~g}, 9.46$ mmol) were stirred overnight at room temperature and then heated to reflux for 90 minutes. This was concentrated to dryness, the residue was dispersed in cyclohexane and filtrated. The filtrate was washed with water, dried over magnesium sulfate and concentrated to dryness to yield the 4-chloropyrazole which NMR spectra feature two detectable tautomers. ${ }^{1} \mathrm{H}$ NMR $\left(\mathrm{CDCl}_{3}\right)$ : major tautomer, $1.35(\mathrm{t}, 3 \mathrm{H}, J=7.0 \mathrm{~Hz}) ; 4.35(\mathrm{q}, 2 \mathrm{H}, J=7.0 \mathrm{~Hz}) ; 10.26(\mathrm{~s}(\mathrm{br}), 1 \mathrm{H})$; minor tautomer, $1.45(\mathrm{t}, 3 \mathrm{H}, J=7.0 \mathrm{~Hz}) ; 4.56(\mathrm{q}, 2 \mathrm{H}, J=7.0 \mathrm{~Hz}) ; 10.12(\mathrm{~s}(\mathrm{br}), 1 \mathrm{H}) .{ }^{13} \mathrm{C}$ $\operatorname{NMR}\left(\mathrm{CDCl}_{3}\right.$, D1 set at $\left.5 \mathrm{~s}\right)$ : major tautomer, 14.6; 69.9; 97.7; $119.0(J=270 \mathrm{~Hz}) ; 132.3(\mathrm{~J}=$ $39 \mathrm{~Hz})$; 157.2; minor tautomer, 18.0; 58.5; 66.0; $117.9(J=274 \mathrm{~Hz}) ; 145.3(J=39 \mathrm{~Hz})$; 166.8. HRMS: calcd for $\mathrm{C}_{6} \mathrm{H}_{7} \mathrm{ClF}_{3} \mathrm{~N}_{2} \mathrm{O}+\mathrm{H}$ : 215.0199; found: 215.0135. Step 2, the hydrolysis procedure described above was applied to this compound and led to the acid 11d 
as a beige power $(0.66 \mathrm{~g}, 67 \%) .{ }^{1} \mathrm{H}$ NMR (DMSO-d6): $1.31(\mathrm{t}, 3 \mathrm{H}, J=7.0 \mathrm{~Hz}) ; 4.23(\mathrm{q}, 2 \mathrm{H}$, $J=7.0 \mathrm{~Hz}$ ); 13.2 (s(br), 2H). ${ }^{13} \mathrm{C}$ NMR (DMSO-d6, D1 set at $5 \mathrm{~s}$ ): 13.0; 65.3; 97.0; 130.9; 158.7; 159.6. HRMS: calcd for $\mathrm{C}_{6} \mathrm{H}_{7} \mathrm{ClN}_{2} \mathrm{O}_{3}-\mathrm{H}$ : 189.0067; found: 189.0066 .

3-propoxy-1H-pyrazole-5-carboxylic acid (11e): Step 1, preparation of 3-propoxy-5(trifluoromethyl)-1H-pyrazole: In dimethylformamide $(100 \mathrm{~mL}$, dried over 4A molecular sieve), 5-(trifluoromethyl)-1H-pyrazol-3-ol ${ }^{38}$ (4.04 g, $\left.0.026 \mathrm{~mol}\right)$, cesium carbonate $(9.52 \mathrm{~g}$, $0.029 \mathrm{~mol})$ and propyliodide $(4.51 \mathrm{~g}, 0.026 \mathrm{~mol})$ were heated at $80{ }^{\circ} \mathrm{C}$ under a moistureprotected atmosphere for 14 hours. This was concentrated to dryness, the residue was dispersed in water and ethyl acetate, the organic layer was washed with water, brine, dried over magnesium sulfate and concentrated. The residue was purified by a chromatography over silica gel (cyclohexane - dichloromethane from $1 / 2$ to $0 / 1$ ) to yield the 3-propoxy-5(trifluoromethyl)-1H-pyrazole as a volatile oil $(2.72 \mathrm{~g}, 52 \%) .{ }^{1} \mathrm{H}$ NMR $\left(\mathrm{CDCl}_{3}\right): 1.04$ (t, 3H, $J=7.5 \mathrm{~Hz}) ; 1.83(\mathrm{~m}, 2 \mathrm{H}) ; 4.07(\mathrm{t}, 2 \mathrm{H}, J=6.5 \mathrm{~Hz}) ; 5.87(\mathrm{~s}, 1 \mathrm{H}) ; 9.69(\mathrm{~s}(\mathrm{br}), 1 \mathrm{H}) .{ }^{13} \mathrm{C} \mathrm{NMR}$ $\left(\mathrm{CDCl}_{3}\right): 10.1 ; 22.3 ; 73.2 ; 85.1 ; 120.5(J=270 \mathrm{~Hz}) ; 140.7(J=39 \mathrm{~Hz}) ; 158.4$. HRMS: calcd for $\mathrm{C}_{7} \mathrm{H}_{9} \mathrm{~F}_{3} \mathrm{~N}_{2} \mathrm{O}+\mathrm{H}$ : 195.0745; found: 195.0715. Step 2: the hydrolysis procedure described above was applied to this compound and led to the acid $11 \mathrm{e}(0.64 \mathrm{~g}, 85 \%)$. ${ }^{1} \mathrm{H}$ NMR (DMSOd6): 0.94 (t, 3H, $J=7.3 \mathrm{~Hz}) ; 1.69(\mathrm{~m}, 2 \mathrm{H}) ; 4.01$ (t, 2H, $J=6.7 \mathrm{~Hz}) ; 6.14$ (s, 1H); 12.96 (s(br), 2H). ${ }^{13} \mathrm{C}$ NMR (DMSO-d6, D1 set at 5 s): $10.2 ; 21.9 ; 70.4 ; 91.9 ; 135.3 ; 160.5 ; 162.4$. HRMS: calcd for $\mathrm{C}_{7} \mathrm{H}_{10} \mathrm{~N}_{2} \mathrm{O}_{3}+\mathrm{H}$ : 171.0957; found: 171.0770 .

3-butoxy-1H-pyrazole-5-carboxylic acid (11f): Step 1, preparation of 3-butoxy-5(trifluoromethyl)-1H-pyrazole: In dimethylformamide $(100 \mathrm{~mL}$, dried over 4A molecular sieve), 5-(trifluoromethyl)-1H-pyrazol-3-ol ${ }^{38}$ (4.06 g, $\left.0.026 \mathrm{~mol}\right)$, cesium carbonate (9.56 g, $0.029 \mathrm{~mol})$ and butylbromide $(3.65 \mathrm{~g}, 0.026 \mathrm{~mol})$ were heated at $80{ }^{\circ} \mathrm{C}$ under a moistureprotected atmosphere for 14 hours. This was concentrated to dryness, the residue was dispersed in water and ethyl acetate, the organic layer was washed with water, brine, dried 
over magnesium sulfate and concentrated. The residue was purified by a chromatography over silica gel (cyclohexane - dichloromethane from $4 / 1$ to $0 / 1$ ) to yield the 3 - butoxy-5(trifluoromethyl)-1H-pyrazole as a volatile oil $(2.19 \mathrm{~g}, 39 \%) .{ }^{1} \mathrm{H} \mathrm{NMR}\left(\mathrm{CDCl}_{3}\right): 0.98$ (t, 3H, $J=7.4 \mathrm{~Hz}) ; 1.48(\mathrm{~m}, 2 \mathrm{H}) ; 1.78(\mathrm{~m}, 2 \mathrm{H}) ; 4.11(\mathrm{t}, 2 \mathrm{H}, J=6.5 \mathrm{~Hz}) ; 5.86(\mathrm{~s}, 1 \mathrm{H}) ; 10.32(\mathrm{~s}(\mathrm{br})$, 1H). ${ }^{13} \mathrm{C} \mathrm{NMR}\left(\mathrm{CDCl}_{3}\right): 13.6 ; 18.9 ; 30.9 ; 71.5 ; 85.0 ; 120.7(J=269 \mathrm{~Hz}) ; 140.7(J=39 \mathrm{~Hz})$; 158.4. HRMS: calcd for $\mathrm{C}_{8} \mathrm{H}_{11} \mathrm{~F}_{3} \mathrm{~N}_{2} \mathrm{O}+\mathrm{H}$ : 209.0902; found: 209.0817. Step 2: the hydrolysis procedure described above was applied to this compound and led to the acid $\mathbf{1 1 f}(0.86 \mathrm{~g}, 90$ \%). ${ }^{1} \mathrm{H}$ NMR (DMSO-d6): 0.91 (t, 3H, $\left.J=7.3 \mathrm{~Hz}\right) ; 1.40(\mathrm{~m}, 2 \mathrm{H}) ; 1.66(\mathrm{~m}, 2 \mathrm{H}) ; 4.05(\mathrm{t}, 2 \mathrm{H}, J$ $=6.5 \mathrm{~Hz}) ; 6.13(\mathrm{~s}, 1 \mathrm{H}) ; 13.01(\mathrm{~s}(\mathrm{br}), 2 \mathrm{H}) .{ }^{13} \mathrm{C}$ NMR (DMSO-d6, D1 set at $\left.5 \mathrm{~s}\right): 13.6 ; 18.6$; 30.7; 68.6; 91.9; 135.2; 160.5; 162.4. HRMS: calcd for $\mathrm{C}_{8} \mathrm{H}_{12} \mathrm{~N}_{2} \mathrm{O}_{3}+\mathrm{H}$ : 185.0926; found: 185.0884

3-isopropoxy-1H-pyrazole-5-carboxylic acid (11g): Step 1, preparation of 3-isopropoxy-5(trifluoromethyl)-1H-pyrazole: In dimethylformamide $(100 \mathrm{~mL}$, dried over 4A molecular sieve), 5-(trifluoromethyl)-1H-pyrazol-3-ol ${ }^{38}$ (5.28 g, $\left.0.034 \mathrm{~mol}\right)$, cesium carbonate $(12.4 \mathrm{~g}$, $0.038 \mathrm{~mol})$ and isopropylbromide $(4.27 \mathrm{~g}, 0.034 \mathrm{~mol})$ were heated at $80^{\circ} \mathrm{C}$ under a moistureprotected atmosphere for 14 hours. This was concentrated to dryness, the residue was dispersed in water and ethyl acetate, the organic layer was washed with water, brine, dried over magnesium sulfate and concentrated. The residue was purified by a chromatography over silica gel (dichloromethane) to yield the 3-isopropoxy-5-(trifluoromethyl)-1H-pyrazole as a volatile oil (3.59 g, 53 \%). ${ }^{1} \mathrm{H}$ NMR $\left(\mathrm{CDCl}_{3}\right): 1.38(\mathrm{~d}, 6 \mathrm{H}, J=6.1 \mathrm{~Hz}) ; 4.50$ (sept, $1 \mathrm{H}, J=6.1$ $\mathrm{Hz}) ; 5.54(\mathrm{~s}, 1 \mathrm{H}) ; 11.13(\mathrm{~s}(\mathrm{br}), 1 \mathrm{H}) .{ }^{13} \mathrm{C} \mathrm{NMR}\left(\mathrm{CDCl}_{3}\right): 21.7 ; 75.2 ; 85.3 ; 120.7(\mathrm{~J}=267 \mathrm{~Hz})$; $141.0(J=39 \mathrm{~Hz})$; 157.0. HRMS: calcd for $\mathrm{C}_{7} \mathrm{H}_{9} \mathrm{~F}_{3} \mathrm{~N}_{2} \mathrm{O}+\mathrm{H}$ : 195.0745; found: 195.0665. Step 2: the hydrolysis procedure described above was applied to this compound and led to the acid $11 \mathrm{~g}\left(0.75 \mathrm{~g}, 87\right.$ \%). ${ }^{1} \mathrm{H}$ NMR (DMSO-d6): 1.25 (d, 6H, $\left.J=6.1 \mathrm{~Hz}\right) ; 4.64$ (sept, $1 \mathrm{H}, J=6.1$ 
$\mathrm{Hz}) ; 6.11(\mathrm{~s}, 1 \mathrm{H}) ; 12.98(\mathrm{~s}(\mathrm{br}), 2 \mathrm{H}) .{ }^{13} \mathrm{C}$ NMR (DMSO-d6, D1 set at $5 \mathrm{~s}$ ): 22.3; 72.0; 93.1; 135.8; 161.0; 161.9. HRMS: calcd for $\mathrm{C}_{7} \mathrm{H}_{10} \mathrm{~N}_{2} \mathrm{O}_{3}+\mathrm{H}$ : 171.0770; found: 171.0740.

3-(pentan-3-yloxy)-1H-pyrazole-5-carboxylic acid (11h): Step 1, preparation of 3-(pentan-3yloxy)-5-(trifluoromethyl)-1H-pyrazole: In dimethylformamide $(100 \mathrm{~mL}$, dried over 4A molecular sieve), 5-(trifluoromethyl)-1H-pyrazol-3-ol ${ }^{38}$ (4.11 g, $\left.0.027 \mathrm{~mol}\right)$, cesium carbonate (9.6 g, $0.029 \mathrm{~mol})$ and 3-bromopentane $(4.08 \mathrm{~g}, 0.027 \mathrm{~mol})$ were heated at $80{ }^{\circ} \mathrm{C}$ under a moisture-protected atmosphere for 14 hours. This was concentrated to dryness, the residue was dispersed in water and ethyl acetate, the organic layer was washed with water, brine, dried over magnesium sulfate and concentrated. The residue was purified by a chromatography over silica gel (cyclohexane - dichloromethane $1 / 2$ to $0 / 1$ ) to yield the 3 (pentan-3-yloxy)-5-(trifluoromethyl)-1H-pyrazole as a volatile oil (2.54 g, $42 \%$ ). ${ }^{1} \mathrm{H}$ NMR $\left(\mathrm{CDCl}_{3}\right): 0.98(\mathrm{t}, 6 \mathrm{H}, J=7.4 \mathrm{~Hz}) ; 1.73(\mathrm{~m}, 4 \mathrm{H}) ; 4.11$ (pent, $\left.1 \mathrm{H}, J=5.8 \mathrm{~Hz}\right) ; 5.82(\mathrm{~s}, 1 \mathrm{H}) ; 8.63$ (s(br), 1H). ${ }^{13} \mathrm{C}$ NMR $\left(\mathrm{CDCl}_{3}\right): 9.3 ; 26.0 ; 84.9 ; 85.7 ; 120.8(J=268 \mathrm{~Hz}) ; 141.3(J=38 \mathrm{~Hz})$; 157.7. HRMS: calcd for $\mathrm{C}_{9} \mathrm{H}_{13} \mathrm{~F}_{3} \mathrm{~N}_{2} \mathrm{O}+\mathrm{H}$ : 223.1058; found: 223.0955. Step 2: the hydrolysis procedure described above was applied to this compound and led to the acid $\mathbf{1 1 h}(0.82 \mathrm{~g}, 96$ \%). ${ }^{1} \mathrm{H}$ NMR (DMSO-d6): 1.00 (t, $\left.6 \mathrm{H}, J=7.5 \mathrm{~Hz}\right) ; 1.74$ (m, 4H); 4.31 (pent, $1 \mathrm{H}, J=5.8 \mathrm{~Hz}$ ); $6.30(\mathrm{~s}, 1 \mathrm{H}) ; 11.90(\mathrm{~s}(\mathrm{br}), 2 \mathrm{H}) .{ }^{13} \mathrm{C}$ NMR (DMSO-d6, D1 set at $\left.5 \mathrm{~s}\right): 9.4 ; 21.1 ; 83.7 ; 93.9$; 135.3; 161.8; 162.7. HRMS: calcd for $\mathrm{C}_{9} \mathrm{H}_{14} \mathrm{~N}_{2} \mathrm{O}_{3}+\mathrm{H}$ : 199.1083; found: 199.1042 .

4-Bromo-3-methyl-1H-pyrazole-5-carboxylic acid (11i): This compound was obtained from 4-bromo-3-methyl-5-(trifluoromethyl)-1H-pyrazole ${ }^{39}$ using the procedure described above as a white power $(0.82 \mathrm{~g}, 88 \%) .{ }^{1} \mathrm{H}$ NMR (DMSO-d6): $2.20(\mathrm{~s}, 3 \mathrm{H}) ; 13.34(\mathrm{~s}(\mathrm{br}), 2 \mathrm{H}) .{ }^{13} \mathrm{C}$ NMR (DMSO-d6, D1 set at 5s): 11.0; 95.8; 137.5 (br); 143.6 (br); 161.7. HRMS: calcd for $\mathrm{C}_{5} \mathrm{H}_{5} \mathrm{BrN}_{2} \mathrm{O}_{2}-\mathrm{H}: 202.9456$; found: 202.9473.

Synthesis of 4-bromo-3-(trifluoromethyl)-1H-pyrazole-5-carboxylic acid (11j). This compound was obtained using a previously described procedure. ${ }^{40}$ A solution of 4-bromo-3- 
methyl-5-(trifluoromethyl)-1H-pyrazole ${ }^{39}$ (0.98 g, $\left.4.27 \mathrm{mmol}\right)$, potassium permanganate (1.7 g, $10.69 \mathrm{mmol})$ in water/tertbutanol $5-1(60 \mathrm{~mL})$ was stirred at $75^{\circ} \mathrm{C}$ for three days. The suspension was filtered, the filtrate made acid using $37 \%$ hydrochloric acid, the resulting precipitate was filtered and dissolved in a $1 \mathrm{~N}$ sodium hydroxide solution. This aqueous layer was washed with dichloromethane twice, and made acid again using $37 \%$ hydrochloric acid. This was extracted with ethyl acetate, the organic layer was washed with brine, dried over magnesium sulfate and concentrated to dryness to yield compound $\mathbf{1 1} \mathbf{j}$ as a white powder (0.64 g, 57 \%). ${ }^{1} \mathrm{H}$ NMR (DMSO-d6): 14.18 (s(br), H); 14.99 (s(br), H). ${ }^{13} \mathrm{C}$ NMR (DMSOd6, D1 set at 5s): 95.2; $121.0(270 \mathrm{~Hz}) ; 135.0 ; 140.7(37 \mathrm{~Hz}) ; 159.1$. HRMS: calcd for $\mathrm{C}_{5} \mathrm{H}_{2} \mathrm{~F}_{3} \mathrm{BrN}_{2} \mathrm{O}_{2}-\mathrm{H}: 258.9153$; found: 258.9208 .

General preparation of amides 13a-d, representative synthesis of methyl 2-(4-(1Hpyrazole-5-carboxamido)piperidin-1-yl)thiazole-5-carboxylate (13a). A calcium chlorideprotected solution of methyl 2-(4-aminopiperidin-1-yl)thiazole-5-carboxylate dihydrochloride dihydrate (12) $)^{23}$ (400 mg, $1.14 \mathrm{mmol}$ ) and $1 H$-pyrazole-4-carboxylic acid (11a) (380 mg, 3.38 mmol) in pyridine $(9 \mathrm{~mL})$ was cooled to $-15{ }^{\circ} \mathrm{C}$. Phosphorus oxychloride $(537 \mathrm{mg}, 3.50$ mmol) was then slowly added and the solution stirred at $-15^{\circ} \mathrm{C}$ for $15 \mathrm{~min}$. This was warmed to $50{ }^{\circ} \mathrm{C}$ few seconds then cooled back to $0{ }^{\circ} \mathrm{C}$ before adding an excess of a saturated solution of sodium hydrogen carbonate. The mixture was extracted four times with ethyl acetate, the organic layers were combined and washed once with brine, dried over magnesium sulfate and concentrated to dryness. The crude residue was purified by chromatography over silica gel (dichloromethane - ethanol, from $97 / 3$ to $95 / 5$ ) to yield product 13a as a white solid (240 mg, $63 \%$ ). ${ }^{1} \mathrm{H}$ NMR (DMSO-d6): note: at high concentration, a minor conformer can also be observed, $1.67(\mathrm{~m}, 2 \mathrm{H}) ; 1.87(\mathrm{~m}, 2 \mathrm{H}) ; 3.25(\mathrm{~m}, 2 \mathrm{H}) ; 3.76(\mathrm{~s}, 3 \mathrm{H}) ; 3.99(\mathrm{~m}, 2 \mathrm{H}) ; 4.01(\mathrm{~m}, 1 \mathrm{H})$; $6.64(\mathrm{~m}, 1 \mathrm{H}) ; 7.80(\mathrm{~m}, 1 \mathrm{H}) ; 7.86(\mathrm{~s}, 1 \mathrm{H}) ; 8.02(\mathrm{~d}, 1 \mathrm{H}, J=8.2 \mathrm{~Hz}) ; 13.20(\mathrm{~s}, 1 \mathrm{H}) .{ }^{13} \mathrm{C} \mathrm{NMR}$ 
(DMSO-d6): 30.4; 45.2; 47.4; 51.6; 105.0; 114.9; 129.8; 146.6; 148.4; 161.1; 161.6; 173.7. HRMS: calcd for $\mathrm{C}_{14} \mathrm{H}_{17} \mathrm{~N}_{5} \mathrm{O}_{3} \mathrm{~S}+\mathrm{H}$ : 336.1130; found: 336.1112 .

Methyl 2-(4-(3-ethoxy-1H-pyrazole-5-carboxamido)piperidin-1-yl)thiazole-5-carboxylate (13b): By using the procedure described above, this compound was obtained as a white solid (70 mg, $32 \%) .{ }^{1} \mathrm{H}$ NMR $\left(\mathrm{CDCl}_{3}\right): 1.41$ (t, 3H, $\left.J=7.0 \mathrm{~Hz}\right) ; 1.66(\mathrm{~m}, 2 \mathrm{H}) ; 2.15(\mathrm{~m}, 2 \mathrm{H}) ; 3.29$ (m, 2H); $3.84(\mathrm{~s}, 3 \mathrm{H}) ; 4.10(\mathrm{~m}, 2 \mathrm{H}) ; 4.20(\mathrm{q}, 2 \mathrm{H}, J=7.0 \mathrm{~Hz}) ; 4.23(\mathrm{~m}, 1 \mathrm{H}) ; 6.03(\mathrm{~s}, 1 \mathrm{H}) ; 6.50$ (s(br), 1H); $7.88(\mathrm{~s}, 1 \mathrm{H}) .{ }^{13} \mathrm{C}$ NMR $\left(\mathrm{CDCl}_{3}\right): 15.2 ; 30.8 ; 45.9 ; 47.7 ; 52.2 ; 64.7 ; 89.8 ; 115.6$; $137.7 ; 148.8 ; 158.4 ; 162.1 ; 163.0 ; 174.2 . \mathrm{LC} / \mathrm{MS}, \mathrm{m} / \mathrm{z}=380(\mathrm{M}+\mathrm{H})$.

Methyl 2-(4-(4-chloro-1H-pyrazole-5-carboxamido)piperidin-1-yl)thiazole-5-carboxylate (13c): By using the procedure described above, this compound was obtained as a white solid (150 mg, 49 \%). ${ }^{1} \mathrm{H}$ NMR (DMSO-d6): 1.67 (m, 2H); 1.88 (m, 2H); 3.28 (m, 2H); 3.75 (s, $3 \mathrm{H}) ; 3.99(\mathrm{~m}, 2 \mathrm{H}) ; 4.07(\mathrm{~m}, 1 \mathrm{H}) ; 7.86(\mathrm{~s}, 1 \mathrm{H}) ; 8.04(\mathrm{~m}, 2 \mathrm{H}) ; 13.51(\mathrm{~s}, 1 \mathrm{H}) .{ }^{13} \mathrm{C} \mathrm{NMR}$ (DMSO-d6): 30.8; 45.7; 47.8; 52.2; 109.3; 115.5; 129.8; 141.6; 148.9; 160.5; 162.1; 174.2. HRMS: calcd for $\mathrm{C}_{14} \mathrm{H}_{16} \mathrm{ClN}_{5} \mathrm{O}_{3} \mathrm{~S}+\mathrm{H}$ : 370.0741 ; found: 370.0757 .

Methyl 2-(4-(4-chloro-3-ethoxy-1H-pyrazole-5-carboxamido)piperidin-1-yl)thiazole-5carboxylate (13d): By using the procedure described above, this compound was obtained as a white solid (60 mg, 4 \%). ${ }^{1} \mathrm{H}$ NMR (DMSO-d6): 1.32 (t, 2H, $J=7.0 \mathrm{~Hz}$ ); 1.65 (m, 2H); 1.93 $(\mathrm{m}, 2 \mathrm{H}) ; 3.33(\mathrm{~m}, 3 \mathrm{H}) ; 3.75(\mathrm{~s}, 3 \mathrm{H}) ; 3.96(\mathrm{~m}, 2 \mathrm{H}) ; 4.08(\mathrm{~m}, 1 \mathrm{H}) ; 4.23(\mathrm{q}, 2 \mathrm{H}, J=7.0 \mathrm{~Hz})$; 7.87 (m, 2H); $12.91(\mathrm{~s}, 1 \mathrm{H}) .{ }^{13} \mathrm{C}$ NMR (DMSO-d6): 15.1; 30.5; 46.1; 47.4; 52.2; 65.3; 93.7; 115.6; 134.4; 148.8; 157.5; 158.2; 162.1; 174.2. HRMS: calcd for $\mathrm{C}_{16} \mathrm{H}_{20} \mathrm{ClN}_{5} \mathrm{O}_{4} \mathrm{~S}+\mathrm{H}$ : 414.1003; found: 414.0985 .

1-(1-Ethoxyethyl)-3-(trifluoromethyl)-1H-pyrazole-5-carboxylic acid (14): Step 1, preparation of 3-(trifluoromethyl)-1H-pyrazole. Ethoxyethene (19.3 g, $0.267 \mathrm{~mol})$ was dissolved in pentane $(120 \mathrm{~mL})$. This was cooled to $0{ }^{\circ} \mathrm{C}$ with an ice bath and trifluoroacetic anhydride $(37.6 \mathrm{~mL}, 0.270 \mathrm{~mol})$ was added slowly. This was stirred overnight at $0{ }^{\circ} \mathrm{C}$ and 
then stirred 3 more hours at room temperature to yield a solution of 4-ethoxy-1,1,1trifluorobut-3-en-2-one which was directly used in the next step. Nota as previously described, ${ }^{41}$ the use of pentane was really optimal for this step. To this pentane solution was added ethanol $(100 \mathrm{~mL})$ and this was cooled to $0^{\circ} \mathrm{C}$ with a large ice bath. Hydrazine hydrate $(15.6 \mathrm{~mL}, 0.321 \mathrm{~mol})$ was slowly added and after an additional 30 minutes of stirring at room temperature, the solution was concentrated to dryness. The residue was dissolved in ethyl acetate and a saturated solution of sodium hydrogen carbonate. The organic layer was washed with a saturated solution of sodium hydrogen carbonate, brine, dried over magnesium sulfate and concentrated to dryness. A distillation at $30 \mathrm{mbar}$ in the rotary evaporator heating with a heat gun and trapping the distillate in a "no return" bulb gave 3-(trifluoromethyl)- $1 H$-pyrazole as a white solid (27.63 g, $75 \%) .{ }^{1} \mathrm{H} \mathrm{NMR}\left(\mathrm{CDCl}_{3}\right): 6.68(\mathrm{~d}, 1 \mathrm{H}, J=2.2 \mathrm{~Hz}) ; 7.73(\mathrm{~m}, 1 \mathrm{H})$; 12.85 (s(br), 1H). Step 2, preparation of 1-(1-ethoxyethyl)-3-(trifluoromethyl)-1H-pyrazole: 3-(trifluoromethyl)-1H-pyrazole (1.02 g, $7.50 \mathrm{mmol})$, ethoxyethene (1.58 g, $21.91 \mathrm{mmol})$, and pyridinium paratoluenesulfonic acid salt $(36 \mathrm{mg}, 0.14 \mathrm{mmol})$ were stirred at room temperature in dichloromethane $(30 \mathrm{~mL})$ for $30 \mathrm{~min}$. The mixture was extracted with dichloromethane, the organic layers were combined and washed with water, brine, and then dried over magnesium sulfate and concentrated to dryness to yield the $N$-protected pyrazole as a yellow liquid (770 $\mathrm{mg}, 49 \%)$ which was used without further purification. ${ }^{1} \mathrm{H}$ NMR $\left(\mathrm{CDCl}_{3}\right): 1.18(\mathrm{t}, 3 \mathrm{H}, J=$ $7.0 \mathrm{~Hz}) ; 1.68(\mathrm{~d}, 3 \mathrm{H} ; J=6.0 \mathrm{~Hz}) ; 3.37(\mathrm{~m}, 1 \mathrm{H}) ; 3.51(\mathrm{~m}, 1 \mathrm{H}) ; 5.59$ (q, 1H, $J=6.0 \mathrm{~Hz}) ; 6.61$ $(\mathrm{d}, 1 \mathrm{H}, J=2.4 \mathrm{~Hz}) ; 7.67(\mathrm{~m}, 1 \mathrm{H})$. Step 3, preparation of 1-(1-ethoxyethyl)-3(trifluoromethyl)-1H-pyrazole-5-carboxylic acid (14). To a solution of 1-(1-ethoxyethyl)-3(trifluoromethyl)-1H-pyrazole $(770 \mathrm{mg}, 3.70 \mathrm{mmol})$ in dry tetrahydrofuran $(50 \mathrm{~mL})$ at $-78{ }^{\circ} \mathrm{C}$ under an atmosphere of argon was slowly added $n$-butyl lithium 2M (2.3 mL, $4.60 \mathrm{mmol})$. This was stirred for 10 minutes and the orange mixture was poured on dry ice dispersed in ether. This was allowed to warm to room temperature and the organic layer was extracted 
with water. The aqueous layer was made acidic with $2 \mathrm{~N}$ hydrochloric acid and extracted with ethyl acetate. The resulting organic layer was washed with water, dried over magnesium sulfate and concentrated to dryness to yield compound 14 as a brown oil (540 $\mathrm{mg}, 58 \%$ ) which was used without further purification.

Methyl 2-(4-(3-(trifluoromethyl)-1H-pyrazole-5-carboxamido)piperidin-1-yl)thiazole-5carboxylate (13e): A calcium chloride protected solution of methyl 2-(4-aminopiperidin-1yl)thiazole-5-carboxylate dihydrochloride dihydrate $(\mathbf{1 2})^{23}(450 \mathrm{mg}, 1.30 \mathrm{mmol})$ and 1-(1ethoxyethyl)-3-(trifluoromethyl)-1H-pyrazole-5-carboxylic acid (14) (420 mg, $1.65 \mathrm{mmol})$ in pyridine $(14 \mathrm{~mL})$ was cooled to $-15^{\circ} \mathrm{C}$. Phosphorus oxychloride $(0.51 \mathrm{~mL}, 5.56 \mathrm{mmol})$ was then slowly added and the solution stirred at $-15{ }^{\circ} \mathrm{C}$ for $15 \mathrm{~min}$. This was warmed to $50{ }^{\circ} \mathrm{C}$ few seconds then cooled back to $0{ }^{\circ} \mathrm{C}$ before adding an excess of a solution of saturated sodium hydrogenocarbonate. The mixture was extracted four times with ethyl acetate, the organic layers were combined and washed once with brine, dried over magnesium sulfate and concentrated to dryness. The resulting crude residue was treated with hydrochloric acid 2M (5 $\mathrm{mL})$ in ethanol $(4 \mathrm{~mL})$ at room temperature overnight. The yellow solution was extracted with ethyl acetate, the organic layer washed with water, brine, dried over magnesium sulfate and concentrated to dryness. The residue was purified by chromatography over silica gel (dichloromethane - ethanol, from 99/1 to 97/3) to yield compound 13e as a pale yellow solid (94 mg, 18 \%). ${ }^{1} \mathrm{H}$ NMR (DMSO-d6): 1.60 (m, 2H); 1.95 (m, 2H); 3.33 (m, 2H); 3.75 (s, 3H); $3.99(\mathrm{~d}, 2 \mathrm{H}) ; 4.12(\mathrm{~m}, 1 \mathrm{H}) ; 7.31(\mathrm{~s}, 1 \mathrm{H}) ; 7.87(\mathrm{~s}, 1 \mathrm{H}) ; 8.49(\mathrm{~m}, 1 \mathrm{H}) ; 14.43(\mathrm{~s}(\mathrm{br}), 1 \mathrm{H}) .{ }^{13} \mathrm{C}$ NMR (DMSO-d6): 30.1; 45.6; 47.1; 54.8; 103.5; 115.1; $121.3(\mathrm{q}, J=267 \mathrm{~Hz}) ; 138.8 ; 141.1$ (q, $J=39 \mathrm{~Hz}) ; 148.3 ; 157.0 ; 161.6 ; 173.7$. HRMS: calcd for $\mathrm{C}_{15} \mathrm{H}_{16} \mathrm{~F}_{3} \mathrm{~N}_{5} \mathrm{O}_{3} \mathrm{~S}+\mathrm{H}: 404.1004$; found: 404.0940.

Preparation of acids 8a-e, representative synthesis of 2-(4-(1H-pyrazole-5carboxamido)piperidin-1-yl)thiazole-5-carboxylic acid (8a): To a solution of methyl 2-(4- 
(1H-pyrazole-3-carboxamido)piperidin-1-yl)thiazole-5-carboxylate (13a) (187 mg, 0.56 mmol) in tetrahydrofuran $(20 \mathrm{~mL})$ was added a solution of lithium hydroxide $(59 \mathrm{mg}, 2.46$ mmol) in water $(6 \mathrm{~mL})$. The mixture was stirred at room temperature overnight. The solvent was removed under vacuum. The mixture was then diluted in water and the aqueous layer washed with ether. Hydrochloric acid $2 \mathrm{~N}$ was added to the aqueous layer added until $\mathrm{pH} 3$, which was then concentrated under vacuum (water pump) at room temperature. The residue was taken up in water and concentrated under vacuum again. This step was repeated three times. The residue was then suspended in a small amount of water at $4{ }^{\circ} \mathrm{C}$ and this was filtered, washed with cold water $\left(4{ }^{\circ} \mathrm{C}\right)$ and dried under vacuum to yield the desired product (8a) as a white powder (110 mg, $61 \%) .{ }^{1} \mathrm{H}$ NMR (DMSO-d6): 1.67 (m, 2H); $1.88(\mathrm{~m}, 2 \mathrm{H})$; $3.25(\mathrm{~m}, 2 \mathrm{H}) ; 3.98(\mathrm{~d}, 2 \mathrm{H}) ; 4.08(\mathrm{~m}, 1 \mathrm{H}) ; 6.68(\mathrm{~d}, 1 \mathrm{H}, J=2.2 \mathrm{~Hz}) ; 7.74(\mathrm{~d}, 1 \mathrm{H}, J=2.2 \mathrm{~Hz})$; $7.77(\mathrm{~s}, 1 \mathrm{H}) ; 8.06(\mathrm{~d}, 1 \mathrm{H}, J=8.1 \mathrm{~Hz}) ; 12.94$ (s, 2H). ${ }^{13} \mathrm{C}$ NMR (DMSO-d6): 30.9; 45.8; 47.8; 105.5; 117.3; 132.2; 145.3; 148.2; 161.0; 163.1; 174.0. HRMS: calcd for $\mathrm{C}_{13} \mathrm{H}_{15} \mathrm{~N}_{5} \mathrm{O}_{3} \mathrm{~S}-\mathrm{H}$ : 320.0817; found: 320.0852 .

2-(4-(3-Ethoxy-1H-pyrazole-5-carboxamido)piperidin-1-yl)thiazole-5-carboxylic acid (8b): By using the procedure described above, this compound was obtained as a solid $(21 \mathrm{mg}, 32$ \%). ${ }^{1} \mathrm{H}$ NMR (DMSO-d6): 1.29 (t, 3H, $\left.J=7.0 \mathrm{~Hz}\right) ; 1.58(\mathrm{~m}, 2 \mathrm{H}) ; 1.90(\mathrm{~m}, 2 \mathrm{H}) ; 3.27(\mathrm{~m}, 2 \mathrm{H})$; $3.98(\mathrm{~m}, 2 \mathrm{H}) ; 4.07(\mathrm{~m}, 1 \mathrm{H}) ; 4.10(\mathrm{q}, 2 \mathrm{H}, J=7.0 \mathrm{~Hz}) ; 6.21(\mathrm{~s}, 1 \mathrm{H}) ; 7.78(\mathrm{~s}, 1 \mathrm{H}) ; 8.15(\mathrm{~d}, 1 \mathrm{H}, J$ $=8.1 \mathrm{~Hz}) ; 12.62(\mathrm{~s}, 1 \mathrm{H}) .{ }^{13} \mathrm{C}$ NMR $(\mathrm{DMSO}-d 6)$ : (one signal missing); 15.1; 30.8; 45.9; 47.7; $65.1 ; 89.15 ; 117.5 ; 148.1 ; 158.9 ; 162.2 ; 163.1 ; 174.0$. HRMS: calcd for $\mathrm{C}_{15} \mathrm{H}_{19} \mathrm{~N}_{5} \mathrm{O}_{4} \mathrm{~S}-\mathrm{H}$ : 364.1096; found: 364.1080 .

2-(4-(4-Chloro-1H-pyrazole-5-carboxamido)piperidin-1-yl)thiazole-5-carboxylic acid (8c): By using the procedure described above, this compound was obtained as a solid (107 mg, 14 \%). ${ }^{1} \mathrm{H}$ NMR (DMSO-d6): 1.67 (m, 2H); $1.88(\mathrm{~m}, 2 \mathrm{H}) ; 3.25(\mathrm{~m}, 2 \mathrm{H}) ; 3.97(\mathrm{~d}, 2 \mathrm{H}) ; 4.06$ (m, $1 \mathrm{H}) ; 7.77(\mathrm{~s}, 1 \mathrm{H}) ; 8.02(\mathrm{~s}, 1 \mathrm{H}) ; 8.09(\mathrm{~d}, 1 \mathrm{H}, J=8.1 \mathrm{~Hz}) ; 12.67(\mathrm{~s}, 1 \mathrm{H}) ; 13.50(\mathrm{~s}, 1 \mathrm{H}) .{ }^{13} \mathrm{C}$ 
NMR (DMSO-d6): 30.2; 45.3; 47.2; 108.8; 116.8; 130.0; 141.1; 147.7; 159.7; 162.6; 173.5. HRMS: calcd for $\mathrm{C}_{13} \mathrm{H}_{14} \mathrm{ClN}_{5} \mathrm{O}_{3} \mathrm{~S}$ - H: 354.0461; found: 354.0428 .

2-(4-(4-Chloro-3-ethoxy-1H-pyrazole-5-carboxamido)piperidin-1-yl)thiazole-5-carboxylic acid (8d): By using the procedure described above, this compound was obtained as a solid (48 mg, $71 \%$ \%). ${ }^{1} \mathrm{H}$ NMR (DMSO-d6): 1.32 (t, 3H, $\left.J=7.0 \mathrm{~Hz}\right) ; 1.65(\mathrm{~m}, 2 \mathrm{H}) ; 1.93(\mathrm{~m}, 2 \mathrm{H}) ; 3.31$ $(\mathrm{m}, 2 \mathrm{H}) ; 3.95(\mathrm{~m}, 2 \mathrm{H}) ; 4.08(\mathrm{~m}, 1 \mathrm{H}) ; 4.23(\mathrm{q}, 2 \mathrm{H}, J=7.0 \mathrm{~Hz}) ; 7.77(\mathrm{~s}, 1 \mathrm{H}) ; 7.89(\mathrm{~d}, 1 \mathrm{H}, J=$ $8.1 \mathrm{~Hz}) ; 12.90$ (s, 1H). ${ }^{13} \mathrm{C}$ NMR (DMSO-d6): 14.6; 30.0; 45.7; 46.6; 64.9; 93.1; 116.9; 134.1; 147.6; 157.1; 157.8; 162.6; 173.5. HRMS: calcd for $\mathrm{C}_{15} \mathrm{H}_{18} \mathrm{ClN}_{5} \mathrm{O}_{4} \mathrm{~S}-\mathrm{H}$ : 398.0707; found: 398.0690 .

2-(4-(3-(Trifluoromethyl)-1H-pyrazole-5-carboxamido)piperidin-1-yl)thiazole-5-carboxylic acid (8e): By using the procedure described above, this compound was obtained as a solid (92 mg, 79 \%). ${ }^{1} \mathrm{H}$ NMR (DMSO-d6): 1.60 (m, 2H); 1.95 (m, 2H); 3.30 (m, 2H); 3.99 (m, 2H); $4.11(\mathrm{~m}, 1 \mathrm{H}) ; 7.31(\mathrm{~s}, 1 \mathrm{H}) ; 7.78(\mathrm{~s}, 1 \mathrm{H}) ; 8.49(\mathrm{~d}, 1 \mathrm{H}, J=8.1 \mathrm{~Hz}) ; 12.64(\mathrm{~s}, 1 \mathrm{H}) ; 14.44(\mathrm{~s}$, 1H). ${ }^{13} \mathrm{C}$ NMR (DMSO-d6): 30.7; 46.2; 47.5; 104.0; 117.6; 121.3 (q, $J=267 \mathrm{~Hz}$ ); 139.4; $141.6(\mathrm{q}, J=38 \mathrm{~Hz}) ; 158.1 ; 157.5 ; 163.1 ; 174.0$. HRMS: calcd for $\mathrm{C}_{14} \mathrm{H}_{14} \mathrm{~F}_{3} \mathrm{~N}_{5} \mathrm{O}_{3} \mathrm{~S}-\mathrm{H}$ : 388.0728; found: 388.0691 .

Preparation of 1-(5-(methoxycarbonyl)thiazol-2-yl)-4-(methylamino)pyridinium bromide (17): In a vial adapted for microwave heating, $N$-methylpyridin-4-amine (15) $(1.04 \mathrm{~g}, 9.6$ mmol) and methyl 2-bromothiazole-5-carboxylate (16) (2.14 g, $9.6 \mathrm{mmol})$ were dissolved in dry acetonitrile $(15 \mathrm{~mL}$, dried over $4 \AA$ molecular sieve). This was heated in a microwave oven for 15 minutes at $100{ }^{\circ} \mathrm{C}$. The resulting suspension was dissolved in methanol and concentrated to dryness to give a brown powder (3.16 g) still containing solvents which was used without further purification in the next step. ${ }^{1} \mathrm{H}$ NMR (DMSO-d6): Major tautomer: 3.06 (s, 3H); $3.91(\mathrm{~s}, 3 \mathrm{H}) ; 7.1(\mathrm{~m}, 1 \mathrm{H}) ; 7.20(\mathrm{~m}, 1 \mathrm{H}) ; 8.40(\mathrm{~s}, 1 \mathrm{H}) ; 8.76(\mathrm{~m}, 1 \mathrm{H}) ; 8.89(\mathrm{~m}, 1 \mathrm{H})$; 
10.02 (s, 1H). ${ }^{13} \mathrm{C}$ NMR (DMSO-d6): 30.3; 53.0; 106.45; 111.1; 128.4; 138.2; 140.4; 146.6; 159.4; 160.9; 164.6. HRMS: calcd for $\mathrm{C}_{11} \mathrm{H}_{12} \mathrm{~N}_{3} \mathrm{O}_{2} \mathrm{~S}^{+}$: 250.0589 ; found: 250.0650 .

Preparation of the mixture of methyl 2-(4-(methylamino)-3,4-dihydropyridin-1 $(2 H)$ yl)thiazole-5-carboxylate (18) and methyl 2-(4-(methylamino)piperidin-1-yl)thiazole-5carboxylate (19): The crude compound $17(3.16 \mathrm{~g})$ was dissolved in methanol $(100 \mathrm{~mL})$ and sodium borohydride $(2.39 \mathrm{~g}, 63.2 \mathrm{mmol})$ was added portion-wise. The resulting solution was stirred for 30 minutes at room temperature, concentrated to dryness and the residue dispersed in water. The aqueous layer was saturated with sodium chloride and extracted four times with ethyl acetate. The organic layers were combined and washed with brine, dried over magnesium sulfate and concentrated to dryness to yield an orange glass $(1.89 \mathrm{~g}, 59 \%$ from compound 15). As seen by ${ }^{1} \mathrm{H}$ NMR and LC/MS, this solid contained a 5/1 ratio of compounds 18 and 19, and this was used in the next step without further purification. ${ }^{1} \mathrm{H}$ NMR $\left(\mathrm{CDCl}_{3}\right)$ : minor compound $191.50(\mathrm{~m}, 2 \mathrm{H}) ; 1.91(\mathrm{~m}, 2 \mathrm{H}) ; 2.04(\mathrm{~m}, 2 \mathrm{H}) ; 2.49(\mathrm{~s}, 3 \mathrm{H})$; $3.21(\mathrm{~m}, 2 \mathrm{H}) ; 3.84(\mathrm{~s}, 3 \mathrm{H}) ; 4.03(\mathrm{~m}, 1 \mathrm{H}) ; 7.87(\mathrm{~s}, 1 \mathrm{H})$; major compound $181.92(\mathrm{~m}, 1 \mathrm{H}) ; 2.07$ $(\mathrm{m}, 1 \mathrm{H}) ; 2.51(\mathrm{~s}, 3 \mathrm{H}) ; 3.29(\mathrm{~m}, 1 \mathrm{H}) ; 3.78(\mathrm{~m}, 2 \mathrm{H}) ; 3.86(\mathrm{~s}, 3 \mathrm{H}) ; 5.17(\mathrm{~m}, 1 \mathrm{H}) ; 6.90(\mathrm{~m}, 1 \mathrm{H})$; $7.93(\mathrm{~s}, 1 \mathrm{H}) . \mathrm{LC} / \mathrm{MS}$, main peak at $m / z=223\left(\mathrm{M}-\mathrm{CH}_{3} \mathrm{NH}\right)$ and secondary peak at $m / z=256$ $(\mathrm{M}+\mathrm{H})$.

Preparation of the dihydropyridine amides 20a-c, representative synthesis of methyl 2-(4( $N$-methyl-1H-pyrazole-3-carboxamido)-3,4-dihydropyridin-1(2H)-yl)thiazole-5-carboxylate (17a): Under an argon atmosphere, the mixture of compound 18 and 19 (0.57 g, $2.24 \mathrm{mmol})$, $1 H$-pyrazole-3-carboxylic acid (11a) $(0.25 \mathrm{~g}, 2.2 \mathrm{mmol})$ and $O$-(benzotriazol-1-yl)- $N, N, N^{\prime}, N^{\prime}-$ tetramethyluronium tetrafluoroborate (TBTU) $(1.51 \mathrm{~g}, 4.7 \mathrm{mmol})$ were dispersed in tetrahydrofuran (50 mL, dried over $4 \AA$ molecular sieves). Diisopropylethylamine $(1.60 \mathrm{~mL}$, $9.4 \mathrm{mmol}$ ) was added and the suspension was stirred at room temperature for four hours. Concentrated ammonia $(10 \mathrm{~mL}, 22 \%)$ was added and this was stirred at room temperature for 
30 minutes before removing the tetrahydrofuran under vacuum. The residue was diluted in ethyl acetate and a saturated solution of sodium hydrogen carbonate. The organic layer was washed with a saturated solution of sodium hydrogen carbonate, brine, dried over magnesium sulfate and concentrated to dryness. The residue was purified by a chromatography over silica gel (dichloromethane - ethanol 95/5) to yield compound 20a as a hard foam $(0.38 \mathrm{~g}, 49 \%$ ), a sample was recrystallized in toluene. ${ }^{1} \mathrm{H}$ NMR (DMSO-d6 at $\left.90{ }^{\circ} \mathrm{C}\right): 2.15(\mathrm{~m}, 2 \mathrm{H}) ; 3.01$ (s, 3H); $3.7(\mathrm{~m}, 1 \mathrm{H}) ; 3.8(\mathrm{~s}, 3 \mathrm{H}) ; 3.97(\mathrm{~m}, 1 \mathrm{H}) ; 5.04(\mathrm{~m}, 1 \mathrm{H}) ; 5.40(\mathrm{~s}(\mathrm{br}), 1 \mathrm{H}) ; 6.57(\mathrm{~d}, 1 \mathrm{H}, J=$ $2.2 \mathrm{~Hz}) ; 7.08(\mathrm{~m}, 1 \mathrm{H}) ; 7.69(\mathrm{~s}(\mathrm{br}), 1 \mathrm{H}) ; 7.92(\mathrm{~s}, 1 \mathrm{H}) ; 12.9(\mathrm{~s}(\mathrm{br}), 1 \mathrm{H})$. HRMS: calcd for $\mathrm{C}_{15} \mathrm{H}_{17} \mathrm{~N}_{5} \mathrm{O}_{3} \mathrm{~S}+\mathrm{H}: 348.1130$; found: 348.1185 .

Methyl 2-(4-(5-ethoxy- $N$-methyl-1 $H$-pyrazole-3-carboxamido)-3,4-dihydropyridin-1(2H)yl)thiazole-5-carboxylate (20b): By using the procedure described above, this compound was obtained as a pale yellow powder $(0.76 \mathrm{~g}, 30 \%) .{ }^{1} \mathrm{H}$ NMR (DMSO- $d 6$ at $\left.90{ }^{\circ} \mathrm{C}\right): 1.33(\mathrm{t}, 3 \mathrm{H}$, $J=7.1 \mathrm{~Hz}) ; 2.13(\mathrm{~m}, 2 \mathrm{H}) ; 2.98(\mathrm{~s}, 3 \mathrm{H}) ; 3.81(\mathrm{~s}, 3 \mathrm{H}) ; 3.96(\mathrm{~m}, 2 \mathrm{H}) ; 4.16(\mathrm{q}, 2 \mathrm{H}, J=7.1 \mathrm{~Hz})$; $5.01(\mathrm{dd}, 1 \mathrm{H}, J=2.8,8.3 \mathrm{~Hz}) ; 5.15(\mathrm{~s}(\mathrm{br}), 1 \mathrm{H}) ; 5.97(\mathrm{~s}, 1 \mathrm{H}) ; 7.10(\mathrm{~d}, 1 \mathrm{H}, J=8.3 \mathrm{~Hz}) ; 7.92(\mathrm{~s}$, $1 \mathrm{H}) ; 12.20$ (s, 1H). HRMS: calcd for $\mathrm{C}_{17} \mathrm{H}_{21} \mathrm{~N}_{5} \mathrm{O}_{4} \mathrm{~S}+\mathrm{H}$ : 392.1393; found: 392.1490 .

Methyl 2-(4-(4-chloro- $N$-methyl-1 $H$-pyrazole-3-carboxamido)-3,4-dihydropyridin-1(2H)yl)thiazole-5-carboxylate (20c): By using the procedure described above, this compound was obtained, after a recrystallization in toluene, as a pale yellow powder still containing traces of toluene (0.53 g, $43 \%) .{ }^{1} \mathrm{H}$ NMR (DMSO-d6 at $\left.90{ }^{\circ} \mathrm{C}\right): 2.15(\mathrm{~m}, 2 \mathrm{H}) ; 2.90(\mathrm{~s}, 3 \mathrm{H}) ; 3.69$ (m, 1H); $3.80(\mathrm{~s}, 3 \mathrm{H}) ; 3.96(\mathrm{~m}, 1 \mathrm{H}) ; 5.00(\mathrm{~m}, 2 \mathrm{H}) ; 7.09(\mathrm{~m}, 1 \mathrm{H}) ; 7.87(\mathrm{~s}(\mathrm{br}), 1 \mathrm{H}) ; 7.91(\mathrm{~s}, 1 \mathrm{H})$; 13.99 (s, 1H). HRMS: calcd for $\mathrm{C}_{17} \mathrm{H}_{21} \mathrm{~N}_{5} \mathrm{O}_{4} \mathrm{~S}+\mathrm{H}$ : 382.0706; found: 382.0741 .

General reduction of compounds $\mathbf{2 0 a}-\mathbf{c}$, representative synthesis of methyl 2-(4-( $N$-methyl1H-pyrazole-5-carboxamido)piperidin-1-yl)thiazole-5-carboxylate (21a): Under a calcium chloride-protected atmosphere, to a solution of compound $\mathbf{2 0 a}(0.37 \mathrm{~g}, 1.06 \mathrm{mmol})$ in dichloromethane $(50 \mathrm{~mL})$ were added trifluoromethane sulfonic acid $(0.47 \mathrm{~mL}, 5.33 \mathrm{mmol})$ 
and triethylsilane $(0.68 \mathrm{ml}, 8.5 \mathrm{mmol})$. This was stirred overnight and concentrated to dryness. The residue was dissolved in ethyl acetate, the organic layer was washed with a saturated solution of sodium hydrogen carbonate, brine, dried over magnesium sulfate and concentrated to dryness. A chromatography over silica gel (dichloromethane - ethanol 97/3) gave compound 21a as a white powder $(0.14 \mathrm{~g}, 38 \%) .{ }^{1} \mathrm{H}$ NMR (DMSO-d6 at $\left.90{ }^{\circ} \mathrm{C}\right): 1.82$ (m, 2H); $1.91(\mathrm{~m}, 2 \mathrm{H}) ; 2.98(\mathrm{~s}, 3 \mathrm{H}) ; 3.19(\mathrm{~m}, 2 \mathrm{H}) ; 3.77(\mathrm{~s}, 3 \mathrm{H}) ; 4.10(\mathrm{~m}, 2 \mathrm{H}) ; 4.62(\mathrm{~m}, 1 \mathrm{H})$; $6.54(\mathrm{~d}, 1 \mathrm{H}, J=2.2 \mathrm{~Hz}) ; 7.76(\mathrm{~d}, 1 \mathrm{H}, J=2.2 \mathrm{~Hz}) ; 7.85(\mathrm{~s}, 1 \mathrm{H})$. HRMS: calcd for $\mathrm{C}_{15} \mathrm{H}_{19} \mathrm{~N}_{5} \mathrm{O}_{3} \mathrm{~S}+\mathrm{H}: 350.1262$; found: 350.1287 .

Methyl 2-(4-(3-ethoxy- $N$-methyl-1H-pyrazole-5-carboxamido)piperidin-1-yl)thiazole-5carboxylate (21b): By using the procedure described above, compound $\mathbf{2 1 b}$ was obtained as glass $(0.10 \mathrm{~g}, 22 \%) .{ }^{1} \mathrm{H}$ NMR (DMSO-d6 at $\left.90{ }^{\circ} \mathrm{C}\right): 1.30(\mathrm{t}, 3 \mathrm{H}, J=7.1 \mathrm{~Hz}) ; 1.80(\mathrm{~m}, 2 \mathrm{H})$; $1.92(\mathrm{~m}, 2 \mathrm{H}) ; 2.96(\mathrm{~s}, 3 \mathrm{H}) ; 3.27(\mathrm{~m}, 2 \mathrm{H}) ; 3.75(\mathrm{~s}, 3 \mathrm{H}) ; 4.10(\mathrm{~m}, 2 \mathrm{H}) ; 4.16(\mathrm{q}, 2 \mathrm{H}, J=7.1 \mathrm{~Hz})$; $4.49(\mathrm{~m}, 1 \mathrm{H}) ; 6.01(\mathrm{~s}, 1 \mathrm{H}) ; 7.86(\mathrm{~s}, 1 \mathrm{H}) ; 12.54(\mathrm{~s}, 1 \mathrm{H})$. HRMS: calcd for $\mathrm{C}_{17} \mathrm{H}_{23} \mathrm{~N}_{5} \mathrm{O}_{4} \mathrm{~S}+\mathrm{H}$ : 394.1549; found: 394.1569. Moreover, another chromatographic fraction contained a substance which was recrystallized in a mixture of cyclohexane and toluene to yield methyl 2(2-ethoxy-5-methyl-4-oxo-5,6,7,8-tetrahydro-4H-6,10-methanopyrazolo[1,5-

c] $[1,3,6]$ triazonin-9(10H)-yl)thiazole-5-carboxylate (22) as white crystals $(0.08 \mathrm{~g}, 16 \%)$. The use of HMQC and HMBC experiment allowed to following signals assignment. ${ }^{1} \mathrm{H}$ NMR (DMSO-d6): 1.23 (t, $\left.J=7.0 \mathrm{~Hz}, 3 \mathrm{H}, \mathrm{OCH}_{2} \mathrm{CH}_{3}\right) ; 1.95\left(\mathrm{~m}, 2 \mathrm{H}, \mathrm{CH}_{2}-7\right) ; 2.54(\mathrm{~m}, 1 \mathrm{H}, 1 / 2 \mathrm{CH}-$ $\left.\mathrm{CH}_{2}-\mathrm{CH}\right) ; 2.66\left(\mathrm{~m}, 1 \mathrm{H}, 1 / 2 \mathrm{CH}-\mathrm{CH}_{2}-\mathrm{CH}\right) ; 2.85\left(\mathrm{~m}, 1 \mathrm{H}, 1 / 2 \mathrm{CH}_{2}-8\right) ; 3.08$ (s, 3H, NMe); 3.78 (s, $3 \mathrm{H}, \mathrm{OMe}$ ); 3.94 (m, 2H, CH-6 and $\left.1 / 2 \mathrm{CH}_{2}-8\right) ; 4.03$ (m, 2H, $\left.\mathrm{OCH}_{2} \mathrm{CH}_{3}\right) ; 6.39$ (s, 1H,CH-3); 6.49 (m, 1H,CH-10); 7.92 (s, 1H, CH-4 pyrazole). ${ }^{13} \mathrm{C}$ NMR (DMSO-d6): $14.4\left(\mathrm{OCH}_{2} \mathrm{CH}_{3}\right)$; $27.0\left(\mathrm{CH}-\mathrm{CH}_{2}-\mathrm{CH}\right) ; 30.0(\mathrm{CH}-7) ; 36.6\left(\mathrm{~N}_{-} \mathrm{CH}_{3}\right) ; 39.5(\mathrm{CH}-8) ; 51.6(\mathrm{CH}-6) ; 51.9\left(\mathrm{OCH}_{3}\right)$; $64.5\left(\mathrm{OCH}_{2} \mathrm{CH}_{3}\right) ; 69.4(\mathrm{CH}-10) ; 98.2(\mathrm{CH}-3) ; 116.6$ (C5'); 139.7 (C3a); $147.2\left(\mathrm{CH}^{\prime} 4^{\prime}\right) ; 156.8$ 
(C-4); 160.9 (C2); 161.5 (C2'); $172.7\left(\mathrm{CO}_{2} \mathrm{Me}\right)$. HRMS: calcd for $\mathrm{C}_{17} \mathrm{H}_{21} \mathrm{~N}_{5} \mathrm{O}_{4} \mathrm{~S}+\mathrm{H}$ : 392.1414; found: 392.1393 .

Methyl 2-(4-(4-chloro- $N$-methyl-1 $H$-pyrazole-5-carboxamido)piperidin-1-yl)thiazole-5carboxylate (21c): By using the procedure described above, this compound was obtained as a glass $(0.07 \mathrm{~g}, 46 \%) .{ }^{1} \mathrm{H}$ NMR (DMSO-d6 at $\left.90{ }^{\circ} \mathrm{C}\right): 1.86(\mathrm{~m}, 4 \mathrm{H}) ; 2.87(\mathrm{~s}, 3 \mathrm{H}) ; 3.18(\mathrm{~m}, 2 \mathrm{H})$; 3.77 (s, 3H); 4.09 (m, 2H); 4.29 (s, 1H); $7.82(\mathrm{~s}, 1 \mathrm{H}) ; 7.87$ (s, 1H); 13.16 (s, 1H). HRMS: calcd for $\mathrm{C}_{15} \mathrm{H}_{18} \mathrm{ClN}_{5} \mathrm{O}_{3} \mathrm{~S}+\mathrm{H}$ : 384.0897; found: 384.0928 .

Alternative preparation of methyl 2-(4-(methylamino)piperidin-1-yl)thiazole-5-carboxylate (19): In a vial adapted for microwave heating, $N$-methylpiperidin-4-amine bishydrochloride (23) (1.0 g, $5.34 \mathrm{mmol})$, methyl 2-bromothiazole-5-carboxylate (16) (1.18 g, $5.34 \mathrm{mmol})$ and diisopropylethylamine $(2.11 \mathrm{~g}, 16.29 \mathrm{mmol})$ were dissolved in dry acetonitrile $(15 \mathrm{~mL}$, dried over $4 \AA$ molecular sieve). This was heated in a microwave oven for 2 hours at $100{ }^{\circ} \mathrm{C}$ and the resulting mixture was concentrated to dryness. The residue was dispersed in brine, a saturated solution of sodium hydrogen carbonate and ethyl acetate. The aqueous layer was extracted four times with ethyl acetate, the organic layers were combined and washed once with brine, dried over sodium carbonate and concentrated to dryness to give an oil $(0.79 \mathrm{~g})$ which was used without further purification in the next step. An LC/MS analysis pointed out the occurrence of the expected $\mathrm{m} / \mathrm{z}=256$ (compound 19) as well as, to a lesser degree, $\mathrm{m} / \mathrm{z}=397$ (compound 24).

Preparation of compounds 21c-j representative synthesis of methyl 2-(4-(4-chloro- $N$ methyl-1H-pyrazole-5-carboxamido)piperidin-1-yl)thiazole-5-carboxylate (21c): The crude mixture containing compound 24 and 19 (0.28 g, $1.09 \mathrm{mmol})$, 4-chloro-1H-pyrazole-5carboxylic acid (11c) (0.16 g, $1.09 \mathrm{mmol})$, and diisopropylethylamine (0.59 g, 4.58mmol) were dissolved in dry tetrahydrofuran $(30 \mathrm{~mL}$, dried over $4 \AA$ molecular sieves). The $O$ (benzotriazol-1-yl)- $N, N, N^{\prime}, N^{\prime}$-tetramethyluronium tetrafluoroborate $(0.74 \mathrm{~g}, 2.29 \mathrm{mmol})$ was 
added and the suspension was stirred at room temperature under a calcium chloride-protected atmosphere overnight. Concentrated ammonia $(10 \mathrm{~mL}, 22 \%)$ was added and this was stirred for two hours. The resulting suspension was diluted in ethyl acetate and a saturated solution of sodium hydrogen carbonate. The organic layer was washed with water, brine, dried over magnesium sulfate and concentrated to dryness. In this specific case, the resulting residue was purified by two consecutive chromatography, the first one over silica gel (dichloromethaneethanol 95/5), the second one over alumina containing $1.5 \%$ of water (dichloromethaneethanol 95/5) to yield compound 21c as a white foam $(0.10 \mathrm{~g}, 9 \%$ from $\mathrm{N}$-methylpiperidin-4amine dihydrochloride (23)). The ${ }^{1} \mathrm{H}$ NMR (DMSO-d6 at $90{ }^{\circ} \mathrm{C}$ ) spectra was identical to the one reported above.

Methyl 2-(4-(4-chloro-3-ethoxy-N-methyl-1H-pyrazole-5-carboxamido)piperidin-1yl)thiazole-5-carboxylate (21d): By following the protocol described above, a residue was obtained which was in this case purified by two consecutive chromatography, the first one over silica gel (dichloromethane-ethanol 97/3), the second one over alumina containing $1.5 \%$ of water (dichloromethane-ethanol 96/4) to yield compound $\mathbf{2 1 d}$ as a glass $(0.17 \mathrm{~g}, 16 \%$ from $N$-methylpiperidin-4-amine dihydrochloride). ${ }^{1} \mathrm{H}$ NMR (DMSO-d6 at $90{ }^{\circ} \mathrm{C}$ ): 1.35 (t, $3 \mathrm{H}, J=$ $7.2 \mathrm{~Hz}) ; 1.80$ (m, 2H); 1.95 (m, 2H); 2.87 (s, 3H); 3.21 (m, 2H); 3.77 (s, 3H); 4.10 (m, 2H); $4.23(\mathrm{~s}(\mathrm{br}), 1 \mathrm{H}) ; 4.27$ (q, 2H, $J=7.2 ; \mathrm{Hz}) ; 7.82(\mathrm{~s}, 1 \mathrm{H}) ; 12.44$ (s(br), 1H). HRMS: calcd for $\mathrm{C}_{17} \mathrm{H}_{22} \mathrm{ClN}_{5} \mathrm{O}_{4} \mathrm{~S}+\mathrm{H}: 428.1159$; found: 428.1169 .

Methyl 2-(4-(N-methyl-3-propoxy-1H-pyrazole-5-carboxamido)piperidin-1-yl)thiazole-5carboxylate (21e): By following the protocol described above, a residue was obtained which was in this case purified by two consecutive chromatography, the first one over silica gel (dichloromethane-ethanol from 97/3), the second one over alumina containing $1.5 \%$ of water (dichloromethane-ethanol 96/4) to yield compound 21e as a glass $(0.14 \mathrm{~g}, 14 \%$ from $\mathrm{N}$ methylpiperidin-4-amine dihydrochloride). ${ }^{1} \mathrm{H}$ NMR (DMSO-d6 at $\left.90{ }^{\circ} \mathrm{C}\right): 0.98(\mathrm{t}, 3 \mathrm{H}, J=$ 
$7.5 \mathrm{~Hz}) ; 1.72(\mathrm{~m}, 2 \mathrm{H}) ; 1.80(\mathrm{~m}, 2 \mathrm{H}) ; 1.91(\mathrm{~m}, 2 \mathrm{H}) ; 2.91$ (s(br), 1/5 of 3H); 2.96 (s (br), 4/5 of $3 \mathrm{H}) ; 3.24(\mathrm{~m}, 2 \mathrm{H}) ; 3.77(\mathrm{~s}, 3 \mathrm{H}) ; 4.08(\mathrm{~m}, 4 \mathrm{H}) ; 4.42(\mathrm{~s}(\mathrm{br}), 4 / 5$ of $1 \mathrm{H}) ; 4.67(\mathrm{~s}(\mathrm{br}), 1 / 5$ of $1 \mathrm{H})$; $5.96(\mathrm{~s}(\mathrm{br}), 1 \mathrm{H}) ; 7.82(\mathrm{~s}, 1 \mathrm{H}) ; 12.12(\mathrm{~s}(\mathrm{br}), 4 / 5$ of $1 \mathrm{H}) ; 12.45(\mathrm{~s}(\mathrm{br}), 1 / 5$ of $1 \mathrm{H})$. HRMS: calcd for $\mathrm{C}_{18} \mathrm{H}_{25} \mathrm{~N}_{5} \mathrm{O}_{4} \mathrm{~S}+\mathrm{H}$ : 408.1706; found: 408.1729 .

Methyl 2-(4-(3-butoxy-N-methyl-1H-pyrazole-5-carboxamido)piperidin-1-yl)thiazole-5carboxylate (21f): By following the protocol described above, a residue was obtained which was in this case purified by two consecutive chromatography, the first one over silica gel (dichloromethane-ethanol from 97/3), the second one over alumina containing $1.5 \%$ of water (dichloromethane-ethanol 96/4) to yield compound 21 as a glass $(0.22 \mathrm{~g}, 18 \%$ from $\mathrm{N}$ methylpiperidin-4-amine dihydrochloride). ${ }^{1} \mathrm{H}$ NMR (DMSO-d6 at $\left.90{ }^{\circ} \mathrm{C}\right): 0.95(\mathrm{t}, 3 \mathrm{H}, J=$ $7.4 \mathrm{~Hz}) ; 1.45(\mathrm{~m}, 2 \mathrm{H}) ; 1.71(\mathrm{~m}, 2 \mathrm{H}) ; 1.81(\mathrm{~m}, 2 \mathrm{H}) ; 1.92(\mathrm{~m}, 2 \mathrm{H}) ; 2.95(\mathrm{~s}(\mathrm{br}), 3 \mathrm{H}) ; 3.24(\mathrm{~m}$, 2H); $3.77(\mathrm{~s}, 3 \mathrm{H}) ; 4.11(\mathrm{~m}, 4 \mathrm{H}) ; 4.42(\mathrm{~s}(\mathrm{br}), 4 / 5$ of $1 \mathrm{H}) ; 4.70(\mathrm{~s}(\mathrm{br}), 1 / 5$ of $1 \mathrm{H}) ; 5.96(\mathrm{~s}(\mathrm{br})$, $1 \mathrm{H}) ; 7.82(\mathrm{~s}, 1 \mathrm{H}) ; 12.13(\mathrm{~s}(\mathrm{br}), 4 / 5$ of $1 \mathrm{H}) ; 12.46(\mathrm{~s}(\mathrm{br}), 1 / 5$ of $1 \mathrm{H})$. HRMS: calcd for $\mathrm{C}_{19} \mathrm{H}_{27} \mathrm{~N}_{5} \mathrm{O}_{4} \mathrm{~S}+\mathrm{H}: 422.1862$; found: 422.1879 .

Methyl 2-(4-(3-isopropoxy-N-methyl-1H-pyrazole-5-carboxamido)piperidin-1-yl)thiazole-5carboxylate (21g): By following the protocol described above, a residue was obtained which was in this case purified by two consecutive chromatography, the first one over silica gel (dichloromethane-ethanol from $97 / 3$ to $96 / 4$ ), the second one over alumina containing $1.5 \%$ of water (dichloromethane-ethanol 96/4) to yield compound $21 \mathrm{~g}$ as a glass $(0.26 \mathrm{~g}, 21 \%$ from $N$-methylpiperidin-4-amine dihydrochloride). ${ }^{1} \mathrm{H}$ NMR (DMSO- $d 6$ at $\left.90{ }^{\circ} \mathrm{C}\right): 1.30(\mathrm{~d}, 6 \mathrm{H}, J=$ $6.1 \mathrm{~Hz}) ; 1.80(\mathrm{~m}, 2 \mathrm{H}) ; 1.91(\mathrm{~m}, 2 \mathrm{H}) ; 2.92(\mathrm{~s}(\mathrm{br}), 1 / 6$ of $3 \mathrm{H}) ; 2.96(\mathrm{~s}(\mathrm{br}), 5 / 6$ of $3 \mathrm{H}) ; 3.23$ (m, 2H); $3.78(\mathrm{~s}, 3 \mathrm{H}) ; 4.10(\mathrm{~m}, 2 \mathrm{H}) ; 4.44(\mathrm{~s}(\mathrm{br}), 1 \mathrm{H}) ; 4.68(\mathrm{~s}(\mathrm{br}), 1 \mathrm{H}) ; 5.93(\mathrm{~s}(\mathrm{br}), 1 \mathrm{H}) ; 7.82$ (s, $1 \mathrm{H}) ; 12.13(\mathrm{~s}(\mathrm{br}), 5 / 6$ of $1 \mathrm{H}) ; 12.43(\mathrm{~s}(\mathrm{br}), 1 / 6$ of $1 \mathrm{H})$. HRMS: calcd for $\mathrm{C}_{18} \mathrm{H}_{25} \mathrm{~N}_{5} \mathrm{O}_{4} \mathrm{~S}+\mathrm{H}$ : 408.1706; found: 408.1739 . 
Methyl 2-(4-(N-methyl-3-(pentan-3-yloxy)-1H-pyrazole-5-carboxamido)piperidin-1yl)thiazole-5-carboxylate (21h): By following the protocol described above, a residue was obtained which was in this case purified by two consecutive chromatography, the first one over silica gel (dichloromethane-ethanol from 97/3), the second one over alumina containing $1.5 \%$ of water (dichloromethane-ethanol $96 / 4)$ to yield compound $21 \mathbf{h}$ as a glass $(0.30 \mathrm{~g}, 26$ $\%$ from $N$-methylpiperidin-4-amine dihydrochloride). ${ }^{1} \mathrm{H}$ NMR (DMSO- $d 6$ at $90{ }^{\circ} \mathrm{C}$ ): 0.93 (t, $6 \mathrm{H}, J=7.6 \mathrm{~Hz}) ; 1.66(\mathrm{~m}, 4 \mathrm{H}) ; 1.80(\mathrm{~m}, 2 \mathrm{H}) ; 1.91(\mathrm{~m}, 2 \mathrm{H}) ; 2.92(\mathrm{~s}(\mathrm{br}), 1 / 6$ of $3 \mathrm{H}) ; 2.96(\mathrm{~s}$ (br), 5/6 of $3 \mathrm{H}) ; 3.23(\mathrm{~m}, 2 \mathrm{H}) ; 3.77(\mathrm{~s}, 3 \mathrm{H}) ; 4.10(\mathrm{~m}, 2 \mathrm{H}) ; 4.35(\mathrm{~s}(\mathrm{br}), 1 \mathrm{H}) ; 4.43(\mathrm{~s}(\mathrm{br}), 1 \mathrm{H})$; $5.95(\mathrm{~s}(\mathrm{br}), 1 \mathrm{H}) ; 7.82(\mathrm{~s}, 1 \mathrm{H}) ; 12.09(\mathrm{~s}(\mathrm{br}), 5 / 6$ of $1 \mathrm{H}) ; 12.42$ (s(br), 1/6 of 1H). HRMS: calcd for $\mathrm{C}_{20} \mathrm{H}_{29} \mathrm{~N}_{5} \mathrm{O}_{4} \mathrm{~S}+\mathrm{H}$ : 436.2019; found: 436.2049 .

Methyl 2-(4-(4-bromo- $N, 3$-dimethyl-1H-pyrazole-5-carboxamido)piperidin-1-yl)thiazole-5carboxylate (21i): By following the protocol described above, a residue was obtained which was in this case purified by two consecutive chromatography, the first one over silica gel (dichloromethane-ethanol 95/5), the second one over alumina containing $1.5 \%$ of water (dichloromethane-ethanol 95/5) to yield compound $21 \mathbf{i}$ as a glass $(0.18 \mathrm{~g}, 15 \%$ from $\mathrm{N}$ methylpiperidin-4-amine dihydrochloride). ${ }^{1} \mathrm{H}$ NMR (DMSO-d6 at $\left.90{ }^{\circ} \mathrm{C}\right): 1.80(\mathrm{~m}, 2 \mathrm{H}) ; 1.92$ (m, 2H); $2.24(\mathrm{~s}, 3 \mathrm{H}) ; 2.86(\mathrm{~s}, 3 \mathrm{H}) ; 3.23(\mathrm{~m}, 2 \mathrm{H}) ; 3.77(\mathrm{~s}, 3 \mathrm{H}) ; 4.10(\mathrm{~m}, 2 \mathrm{H}) ; 4.29(\mathrm{~s}(\mathrm{br}), 1 \mathrm{H})$; $7.82(\mathrm{~s}, 1 \mathrm{H}) ; 12.90(\mathrm{~s}(\mathrm{br}), 1 \mathrm{H})$. HRMS: calcd for $\mathrm{C}_{16} \mathrm{H}_{20} \mathrm{BrN}_{5} \mathrm{O}_{3} \mathrm{~S}+\mathrm{H}$ : 442.0548; found: 442.0555 .

Methyl 2-(4-(4-bromo- $N$-methyl-3-(trifluoromethyl)-1 $H$-pyrazole-5-carboxamido)piperidin1-yl)thiazole-5-carboxylate (21j): By following the protocol described above, a residue was obtained which was in this case purified by a chromatography over silica gel (dichloromethane-ethanol 96/4) followed by a dispersion in boiling toluene which led to pure compound $21 \mathbf{j}$ (0.26 g, $19 \%$ from $N$-methylpiperidin-4-amine dihydrochloride) as a white powder. ${ }^{1} \mathrm{H}$ NMR (DMSO-d6 at $\left.90{ }^{\circ} \mathrm{C}\right): 1.81(\mathrm{~m}, 2 \mathrm{H}) ; 1.97(\mathrm{~m}, 2 \mathrm{H}) ; 2.87(\mathrm{~s}, 3 \mathrm{H}) ; 3.23$ (m, 
2H); 3.77 (s, 3H); $4.10(\mathrm{~m}, 2 \mathrm{H}) ; 4.23(\mathrm{~s}(\mathrm{br}), 1 \mathrm{H}) ; 7.82(\mathrm{~s}, 1 \mathrm{H}) ; 14.31$ (s, 1H). HRMS: calcd for $\mathrm{C}_{16} \mathrm{H}_{17} \mathrm{BrF}_{3} \mathrm{~N}_{5} \mathrm{O}_{3} \mathrm{~S}+\mathrm{H}$ : 496.0266; found: 496.0331 .

2-(4-(N-Methyl-1H-pyrazole-5-carboxamido)piperidin-1-yl)thiazole-5-carboxylic acid (9a): Compound 21a $(0.11 \mathrm{~g}, 0.32 \mathrm{mmol})$ and lithium hydroxide $(0.13 \mathrm{~g}, 3.1 \mathrm{mmol})$ were stirred in water $(10 \mathrm{~mL})$ and tetrahydrofuran $(30 \mathrm{~mL})$ overnight. This was concentrated to dryness, made acidic with hydrochloric acid and, since there was no precipitate in these cases, the aqueous phase was extracted with ethyl acetate five times. The organic layers were combined and washed with brine once, dried over magnesium sulfate and concentrated to dryness to yield compound 9a as a white powder $(0.01 \mathrm{~g}, 10 \%) .{ }^{1} \mathrm{H}$ NMR (DMSO-d6 at $\left.90{ }^{\circ} \mathrm{C}\right): 1.91$ $(\mathrm{m}, 4 \mathrm{H}) ; 2.99(\mathrm{~s}, 3 \mathrm{H}) ; 3.18(\mathrm{~m}, 2 \mathrm{H}) ; 4.10(\mathrm{~m}, 2 \mathrm{H}) ; 4.62(\mathrm{~m}, 1 \mathrm{H}) ; 6.55(\mathrm{~d}, 1 \mathrm{H}, J=2.2 \mathrm{~Hz})$; $7.67(\mathrm{~d}, 1 \mathrm{H}, J=2.2 \mathrm{~Hz}) ; 7.75(\mathrm{~s} 1 H) ; 12.88(\mathrm{~s}, 1 \mathrm{H})$. HRMS: calcd for $\mathrm{C}_{14} \mathrm{H}_{17} \mathrm{~N}_{5} \mathrm{O}_{3} \mathrm{~S}+\mathrm{H}$ : 336.1130; found: 336.1145 .

2-(4-(3-Ethoxy- $N$-methyl-1H-pyrazole-5-carboxamido)piperidin-1-yl)thiazole-5-carboxylic acid (9b): By using the procedure described above, this compound was obtained as a pale yellow powder $(0.06 \mathrm{~g}, 89 \%) .{ }^{1} \mathrm{H}$ NMR (DMSO-d6 at $\left.90{ }^{\circ} \mathrm{C}\right): 1.33(\mathrm{t}, 3 \mathrm{H}, J=7.1 \mathrm{~Hz}) ; 1.91$ $(\mathrm{m}, 4 \mathrm{H}) ; 2.96(\mathrm{~s}, 3 \mathrm{H}) ; 3.21(\mathrm{~m}, 2 \mathrm{H}) ; 4.09(\mathrm{~m}, 2 \mathrm{H}) ; 4.16(\mathrm{q}, 2 \mathrm{H}, J=7.1 \mathrm{~Hz}) ; 4.48(\mathrm{~m}, 1 \mathrm{H})$; $5.94(\mathrm{~s}, 1 \mathrm{H}) ; 7.76(\mathrm{~s}, 1 \mathrm{H}) ; 12.58(\mathrm{~s}, 1 \mathrm{H}) . \mathrm{HRMS}$ : calcd for $\mathrm{C}_{16} \mathrm{H}_{21} \mathrm{~N}_{5} \mathrm{O}_{4} \mathrm{~S}+\mathrm{H}: 380.1393$; found: 380.1395 .

2-(4-(4-Chloro- $N$-methyl-1H-pyrazole-5-carboxamido)piperidin-1-yl)thiazole-5-carboxylic acid (9c): By using the procedure described above, this compound was obtained as a white powder $(0.04 \mathrm{~g}, 59 \%) .{ }^{1} \mathrm{H}$ NMR (DMSO-d6 at $90{ }^{\circ} \mathrm{C}$ ) $1.81(\mathrm{~m}, 2 \mathrm{H}) ; 1.90(\mathrm{~m}, 2 \mathrm{H}) ; 2.86$ (s, 3H); 3.15 (m, 2H); 4.08 (m, 2H); 4.27 (s(br), 1H); 7.74 (s, 1H); 7.83 (s, 1H). HRMS: calcd for $\mathrm{C}_{14} \mathrm{H}_{16} \mathrm{ClN}_{5} \mathrm{O}_{3} \mathrm{~S}+\mathrm{H}: 370.0741$; found: 370.0741 .

2-(4-(4-chloro-3-ethoxy-N-methyl-1H-pyrazole-5-carboxamido)piperidin-1-yl)thiazole-5carboxylic acid (9d): Compound 21d (0.15 g, $0.35 \mathrm{mmol})$, lithium hydroxide ( $0.15 \mathrm{~g}, 3.5$ 
mmol) were stirred in water $(5 \mathrm{~mL})$ and tetrahydrofuran $(10 \mathrm{~mL})$ overnight. This was concentrated to dryness. The residue was dissolved in a small amount of water saturated with sodium chloride and made acid with the minimum amount of $1 \mathrm{~N}$ hydrochloric acid. The resulting suspension was extracted with ethyl acetate, the organic layer was washed with brine, dried over magnesium sulfate and concentrated to dryness. The residue was dispersed in a small amount of water, this was filtered and dried to give compound $\mathbf{9 d}$ as a white powder $(0.11 \mathrm{~g}, 75 \%) .{ }^{1} \mathrm{H}$ NMR (DMSO-d6 at $\left.90{ }^{\circ} \mathrm{C}\right): 1.35(\mathrm{t}, 3 \mathrm{H}, J=7.1 \mathrm{~Hz}) ; 1.81(\mathrm{~m}, 2 \mathrm{H})$; $1.92(\mathrm{~m}, 2 \mathrm{H}) ; 2.87(\mathrm{~s}, 3 \mathrm{H}) ; 3.18(\mathrm{~m}, 2 \mathrm{H}) ; 4.08(\mathrm{~m}, 2 \mathrm{H}) ; 4.22(\mathrm{~s}(\mathrm{br}), 1 \mathrm{H}) ; 4.27(\mathrm{q}, 2 \mathrm{H}, J=7.1$; $\mathrm{Hz}) ; .74(\mathrm{~s}, 1 \mathrm{H}) ; 12.28(\mathrm{~s}(\mathrm{br}), 1 \mathrm{H})$. HRMS: calcd for $\mathrm{C}_{16} \mathrm{H}_{20} \mathrm{ClN}_{5} \mathrm{O}_{4} \mathrm{~S}+\mathrm{H}$ : 414.1003; found: 414.1021.

2-(4-(N-methyl-3-propoxy-1H-pyrazole-5-carboxamido)piperidin-1-yl)thiazole-5-carboxylic acid (9e): Compound 21e (0.12 g, $0.29 \mathrm{mmol})$, lithium hydroxide $(0.12 \mathrm{~g}, 2.8 \mathrm{mmol})$ were stirred in water $(5 \mathrm{~mL})$ and tetrahydrofuran $(10 \mathrm{~mL})$ overnight. This was concentrated to dryness. The residue was dissolved in a small amount of water saturated with sodium chloride and made acid with the minimum amount of $1 \mathrm{~N}$ hydrochloric acid. The resulting suspension was extracted with ethyl acetate, the organic layer was washed with brine, dried over magnesium sulfate and concentrated to dryness to yield compound $9 \mathbf{e}$ as a white powder $(0.07$ g, $60 \%$ ). ${ }^{1} \mathrm{H}$ NMR (DMSO- $d 6$ at $\left.90{ }^{\circ} \mathrm{C}\right): 0.94(\mathrm{t}, 3 \mathrm{H}, J=7.4 \mathrm{~Hz}) ; 1.73(\mathrm{~m}, 2 \mathrm{H}) ; 1.80(\mathrm{~m}, 2 \mathrm{H})$; $1.91(\mathrm{~m}, 2 \mathrm{H}) ; 2.96(\mathrm{~s}, 3 \mathrm{H}) ; 3.20(\mathrm{~m}, 2 \mathrm{H}) ; 4.06(\mathrm{t}, 2 \mathrm{H}, J=6.6 \mathrm{~Hz}) ; 4.09(\mathrm{~m}, 2 \mathrm{H}) ; 4.48(\mathrm{~m}, 1 \mathrm{H})$; $5.94(\mathrm{~s}, 1 \mathrm{H}) ; 7.75(\mathrm{~s}, 1 \mathrm{H}) ; 12.16(\mathrm{~s}(\mathrm{br}), 1 \mathrm{H}) . \mathrm{HRMS}$ : calcd for $\mathrm{C}_{17} \mathrm{H}_{23} \mathrm{~N}_{5} \mathrm{O}_{4} \mathrm{~S}+\mathrm{H}: 394.1549$; found: 394.1538 .

2-(4-(3-butoxy-N-methyl-1H-pyrazole-5-carboxamido)piperidin-1-yl)thiazole-5-carboxylic acid (9f): Compound $21 f(0.2 \mathrm{~g}, 0.47 \mathrm{mmol})$, lithium hydroxide $(0.2 \mathrm{~g}, 4.7 \mathrm{mmol})$ were stirred in water $(5 \mathrm{~mL})$ and tetrahydrofuran $(10 \mathrm{~mL})$ overnight. This was concentrated to dryness. The residue was dissolved in a small amount of water saturated with sodium chloride and 
made acid with the minimum amount of $1 \mathrm{~N}$ hydrochloric acid. The resulting suspension was extracted with ethyl acetate, the organic layer was washed with brine, dried over magnesium sulfate and concentrated to dryness to yield compound 9 f as a white powder $(0.09 \mathrm{~g}, 46 \%)$. ${ }^{1} \mathrm{H}$ NMR (DMSO-d6 at $\left.90{ }^{\circ} \mathrm{C}\right): 0.94$ (t, 3H, $\left.J=7.3 \mathrm{~Hz}\right) ; 1.44(\mathrm{~m}, 2 \mathrm{H}) ; 1.70$ (m, 2H); 1.79 (m, 2H); $1.91(\mathrm{~m}, 2 \mathrm{H}) ; 2.96(\mathrm{~s}, 3 \mathrm{H}) ; 3.21(\mathrm{~m}, 2 \mathrm{H}) ; 4.09(\mathrm{~m}, 2 \mathrm{H}) ; 4.10(\mathrm{t}, 2 \mathrm{H}, J=6.6 \mathrm{~Hz}) ; 4.48(\mathrm{~m}$, $1 \mathrm{H}) ; 5.94(\mathrm{~s}, 1 \mathrm{H}) ; 7.75(\mathrm{~s}, 1 \mathrm{H}) ; 11.80(\mathrm{~s}(\mathrm{br}), 1 \mathrm{H})$. HRMS: calcd for $\mathrm{C}_{18} \mathrm{H}_{25} \mathrm{~N}_{5} \mathrm{O}_{4} \mathrm{~S}+\mathrm{H}$ : 408.1706; found: 408.1734 .

2-(4-(3-isopropoxy-N-methyl-1H-pyrazole-5-carboxamido)piperidin-1-yl)thiazole-5-

carboxylic acid $(\mathbf{9 g})$ : Compound $\mathbf{2 1 g}(0.24 \mathrm{~g}, 0.58 \mathrm{mmol})$, lithium hydroxide $(0.24 \mathrm{~g}, 5.7$ mmol) were stirred in water $(5 \mathrm{~mL})$ and tetrahydrofuran $(10 \mathrm{~mL})$ overnight. This was concentrated to dryness. The residue was dissolved in a small amount of water saturated with sodium chloride and made acid with the minimum amount of $1 \mathrm{~N}$ hydrochloric acid. The resulting suspension was extracted with ethyl acetate, the organic layer was washed with brine, dried over magnesium sulfate and concentrated to dryness to yield compound $\mathbf{9 g}$ as a white powder (0.13 g, $56 \%) .{ }^{1} \mathrm{H}$ NMR (DMSO-d6 at $\left.90{ }^{\circ} \mathrm{C}\right): 1.30(\mathrm{~d}, 6 \mathrm{H}, J=6.3 \mathrm{~Hz}) ; 1.80$ (m, 2H); $1.91(\mathrm{~m}, 2 \mathrm{H}) ; 2.96(\mathrm{~s}, 3 \mathrm{H}) ; 3.20(\mathrm{~m}, 2 \mathrm{H}) ; 4.08(\mathrm{~m}, 2 \mathrm{H}) ; 4.48(\mathrm{~m}, 1 \mathrm{H}) ; 4.63$ (sept, 1H, $J=6.3 \mathrm{~Hz}) ; 5.92(\mathrm{~s}, 1 \mathrm{H}) ; 7.75(\mathrm{~s}, 1 \mathrm{H}) ; 12.02(\mathrm{~s}(\mathrm{br}), 1 \mathrm{H})$. HRMS: calcd for $\mathrm{C}_{17} \mathrm{H}_{23} \mathrm{~N}_{5} \mathrm{O}_{4} \mathrm{~S}+\mathrm{H}$ : 394.1549; found: 394.1562.

2-(4-(N-methyl-3-(pentan-3-yloxy)-1H-pyrazole-5-carboxamido)piperidin-1-yl)thiazole-5carboxylic acid (9h): Compound $21 \mathrm{~h}(0.28 \mathrm{~g}, 0.64 \mathrm{mmol})$, lithium hydroxide $(0.28 \mathrm{~g}, 6.6$ mmol) were stirred in water $(5 \mathrm{~mL})$ and tetrahydrofuran $(10 \mathrm{~mL})$ overnight. This was concentrated to dryness. The residue was dissolved in a small amount of water saturated with sodium chloride and made acid with the minimum amount of $1 \mathrm{~N}$ hydrochloric acid. The resulting suspension was dispersed in ethyl acetate and this now biphasic suspension was filtered, washed with water and ethyl acetate and dried under vacuum to yield compound $\mathbf{9 h}$ 
as a white powder $(0.19 \mathrm{~g}, 70 \%) .{ }^{1} \mathrm{H}$ NMR (DMSO- $d 6$ at $\left.90{ }^{\circ} \mathrm{C}\right): 0.92(\mathrm{t}, 6 \mathrm{H}, J=7.2 \mathrm{~Hz})$; $1.65(\mathrm{~m}, 4 \mathrm{H}) ; 1.74(\mathrm{~m}, 2 \mathrm{H}) ; 1.89(\mathrm{~m}, 2 \mathrm{H}) ; 2.95(\mathrm{~s}(\mathrm{br}), 1 \mathrm{H}) ; 3.0(\mathrm{~m}, 2 \mathrm{H}) ; 4.01(\mathrm{~m}, 2 \mathrm{H}) ; 4.27$ (pent, 1H, $J=5.8 \mathrm{~Hz}) ; 4.43(\mathrm{~m}, 1 \mathrm{H}) ; 5.90(\mathrm{~s}, 1 \mathrm{H}) ; 7.26(\mathrm{~s}, 1 \mathrm{H}) ; 12.24$ (s(br), 1H). HRMS: calcd for $\mathrm{C}_{19} \mathrm{H}_{27} \mathrm{~N}_{5} \mathrm{O}_{4} \mathrm{~S}+\mathrm{H}: 422.1862$; found: 422.1862 .

2-(4-(4-Bromo- $N, 3-$ dimethyl-1H-pyrazole-5-carboxamido)piperidin-1-yl)thiazole-5-

carboxylic acid (9i): Compound $21 \mathbf{i}(0.13 \mathrm{~g}, 0.29 \mathrm{mmol})$, lithium hydroxide (0.12 g, 2.8 mmol) were stirred in water $(10 \mathrm{~mL})$ and tetrahydrofuran $(30 \mathrm{~mL})$ overnight. This was concentrated to dryness. The residue was dissolved in a small amount of water and made acid with the minimum amount of $1 \mathrm{~N}$ hydrochloric acid. The resulting precipitate was filtered and dried under vacuum at $50{ }^{\circ} \mathrm{C}$ to yield acid $9 \mathbf{i}$ as a white powder $(0.06 \mathrm{~g}, 47 \%) .{ }^{1} \mathrm{H}$ NMR (DMSO-d6 at $\left.90{ }^{\circ} \mathrm{C}\right): 1.80(\mathrm{~m}, 2 \mathrm{H}) ; 1.92(\mathrm{~m}, 2 \mathrm{H}) ; 2.23(\mathrm{~s}, 3 \mathrm{H}) ; 2.85(\mathrm{~s}, 3 \mathrm{H}) ; 3.15(\mathrm{~m}, 2 \mathrm{H})$; $4.07(\mathrm{~m}, 2 \mathrm{H}) ; 4.28(\mathrm{~s}(\mathrm{br}), 1 \mathrm{H}) ; 7.74(\mathrm{~s}, 1 \mathrm{H}) . \mathrm{HRMS}$ : calcd for $\mathrm{C}_{15} \mathrm{H}_{18} \mathrm{BrN}_{5} \mathrm{O}_{3} \mathrm{~S}+\mathrm{H}: 428.0392$; found: 428.0397 .

2-(4-(4-Bromo- $N$-methyl-3-(trifluoromethyl)-1H-pyrazole-5-carboxamido)piperidin-1-

yl)thiazole-5-carboxylic acid (9j): By following the protocol described above, this acid was obtained as a white powder $(0.14 \mathrm{~g}, 72 \%) .{ }^{1} \mathrm{H}$ NMR (DMSO-d6 at $\left.90{ }^{\circ} \mathrm{C}\right): 1.80(\mathrm{~m}, 2 \mathrm{H}) ; 1.95$ (m, 2H); $2.87(\mathrm{~s}, 3 \mathrm{H}) ; 3.20(\mathrm{~m}, 2 \mathrm{H}) ; 4.10(\mathrm{~m}, 2 \mathrm{H}) ; 4.22$ (s(br), 1H); 7.75 (s, 1H). HRMS: calcd for $\mathrm{C}_{15} \mathrm{H}_{15} \mathrm{BrF}_{3} \mathrm{~N}_{5} \mathrm{O}_{3} \mathrm{~S}+\mathrm{H}$ : 482.0109; found: 482.0146 .

\section{Acknowledgment}

This work was supported by the Agence Nationale de la Recherche (ANR), grant ANR-11CRNT-0004, in the context of the investment program "GLOBAL CARE", an association of the Instituts Carnot "Pasteur-Maladies Infectieuses", "Curie-Cancer", "Voir et Entendre", "Institut du Cerveau et de la moelle Epiniere" and the Consortium pour l'Acceleration de 
l'Innovation et de son Transfert dans le domaine du Lymphome (CALYM). Dr. Daniel Larzul, Institut Pasteur, and Dr. Emile Bisagni are acknowledged for their constant interest and support.

\section{References}

(1) US Department of Health and Human Services Centers for disease control and prevention, 2013.

(2) Payne, D. J.; Gwynn, M. N.; Holmes, D. J.; Pompliano, D. L. Nature Rev. 2007, 6, 29.

(3) Mayer, C.; Janin, Y. L. Chem. Rev. 2014, 114, 2313.

(4) Sherer, B. A.; Hull, K.; Green, O.; Basarab, G.; Hauck, S.; Hill, P.; Loch, J. T.; Mullen, G.; Bist, S.; Bryant, J.; Boriack-Sjodin, A.; Read, J.; DeGrace, N.; UriaNickelsen, M.; llingworth, R. N.; Eakin, A. E. Bioorg. Med. Chem. Lett. 2011, 21, 7416.

(5) Basarab, G.; Dangel, B.; Fleming, P. R.; Gravestock, M. B.; Green, O.; Hauck, S. I.; Hill, P.; Hull, K. G.; Mullen, G.; Sherer, B.; Zhou, F. Patent WO2006087543, 2006.

(6) Basarab, G.; Ni, H.; Sherer, B.; Zhou, F. Patent WO 2007071965, 2007.

(7) Peer Mohamed, S. H.; Waterson, D. Patent WO 2010067125, 2010.

(8) Shirude, P. S.; Hameed, S. In Annu. Rep. Med. Chem.; Desai, M. C., Ed.; Academic Press: New York, 2012; Vol. 47; p 319.

(9) Soneda, T.; Takeshita, H.; Kagoshima, Y.; Yamamoto, Y.; Hosokawa, T.; Konosu, T.; Masuda, N.; Uchida, T.; Achiwa, I.; Fujisawa, T.; Yokomizo, A.; Noguchi, T. Patent EP 2226322, 2009. 
(10) Soneda, T.; Takeshita, H.; Kagoshima, Y.; Yamamoto, Y.; Hosokawa, T.; Konosu, T.; Masuda, N.; Uchida, T.; Achiwa, I.; Kuroyanagi, J.; Yokomizo, A.; Noguchi, T. Patent US 20140073622, 2014.

(11) Sharma, L.; Sattigeri, J. A.; Kumar, N.; Yadav, A.; Momin, R.; Ahmed, S.; Cliffe, I. A.; Bhatnagar, P. K.; Gosh, S.; Raj, V. S.; Upadhyay, D. J. Patent WO 2010013222 , 2010 .

(12) Gravestock, M. B.; Hull, K. G.; Fleming, P. R. Patent WO 2008020229, 2008.

(13) Basarab, G. S. Patent WO 2008020227, 2008.

(14) Basarab, G. S.; Hill, P.; Hull, K. G. Patent WO 2008020222, 2008.

(15) Bist, S.; Hauck, S. I.; Hull, K. G. Patent WO 2006022608, 2006.

(16) Hull, K. G.; Bist, S. Patent WO 2006087544, 2006.

(17) Zidar, N.; Macut, H.; Tomašič, T.; Brvar, M.; Montalvão, S.; Tammela, P.; Solmajer, T.; Peterlin, M., L.; Ilaš, J.; Kikelj, D. J. Med. Chem. 2015, 58, 6179.

(18) Sherer, B.; Zhou, F. Patent WO 2006087548, 2006.

(19) Basarab, G. S.; Gravestock, M. B.; Hauck, S. I. Patent WO 2006092599, 2006.

(20) Tomašič, T.; Katsamakas, S.; Hodnik, Ž.; Ilaš, J.; Brvar, M.; Solmajer, T.; Montalvão, S.; Tammela, P.; Banjanac, M.; Ergović, G.; Anderluh, M.; Mašič, L. P.; Kikelj, D. J. Med. Chem. 2015, 58, 5501 .

(21) Basarab, G. S.; Hill, P. J.; Garner, C. E.; Hull, K.; Green, O.; Sherer, B. A.; Dangel, P. B.; Manchester, J. I.; Bist, S.; Hauck, S.; Zhou, F.; Uria-Nickelsen, M.; Illingworth, R.; Alm, R.; Rooney, M.; Eakin, A. E. J. Med. Chem. 2014, 57, 6060.

(22) Ermolenko, M. S.; Guillou, S.; Janin, Y. L. Tetrahedron 2013, 69, 257.

(23) Breeze, A. L.; Green, O. M.; Hull, K. G.; Ni, H.; Hauck, S. I.; Mullen, G. B.; Hales, N. J.; Timms, D. Patent WO2005026149, 2005. 
(24) Rijkers, D. T. S.; Adams, H. P. M. S.; Hemker, H. C.; Tesser, G. I. Tetrahedron 1995, $51,11235$.

(25) Tung, J. S.; Garofalo, A. W.; Pleiss, M. A.; Wu, J.; Wone, D. W. G.; Guinn, A. C.; Dressen, D. B.; Neitz, R. J.; Marugg, J. Patent WO2004098589, 2004.

(26) Burnett, M. N.; Johnson, C. K. Oak Ridge National Laboratory Report 1996, ORNL.

(27) Bruno, I. J.; Cole, J. C.; Kessler, M.; Luo, J.; Motherwell, W. D. S.; Purkis, L. H.; Smith, B. R.; Taylor, R.; Cooper, R. I.; Harris, S. E.; Orpen, A. G. J. Chem. Inf. Comput. Sci. 2004, 44, 2133.

(28) Macrae, C. F.; Bruno, I. J.; Chisholm, J. A.; Edgington, P. R.; McCabe, P.; Pidcock, E.; Rodriguez-Monge, L.; Taylor, R.; van de Streek, J.; Wood, P. A. J. Appl. Cryst. 2008, $41,466$.

(29) Cremer, D.; Pople, J. A. J. Am. Chem. Soc. 1975, 97, 1354.

(30) Manoury, P.; Binet, J.; Defosse, G. Patent US 4820710, 1989.

(31) Int. J. Antimicrob. Agents 2003, 21, 364.

(32) Aubry, A.; Pan, X. S.; Fisher, L. M.; Jarlier, V.; Cambau, E. Antimicrob. Agents Chemother. 2004, 48, 1281.

(33) Roué, M.; Agrawal, A.; Spitzfaden, C.; Volker, C.; Mossakowska, D.; Mayer, C.; Bax, B. Acta Cryst. Sect. F 2013, 69, 679.

(34) Rigaku/MSC CrystalClear. Rigaku/MSC Inc.

(35) Sheldrick, G. M. Acta Cryst. 2008, A64, 112.

(36) Sheldrick, G. M. Acta Cryst. 2015, C71, 3.

(37) Guillou, S.; Bonhomme, F. J.; Janin, Y. L. Synthesis 2008, 3504.

(38) Gilman, H.; Tolman, L.; Yeoman, F.; Woods, L. A.; Shirley, D. A.; Avakian, S. J. Am. Chem. Soc. 1946, 68, 426.

(39) Jeon, S. L.; Choi, J. H.; Kim, B. T.; Jeong, I. H. J. Fluorine Chem. 2007, 128, 1191. 
(40) Pelcman, B.; Sanin, A.; Nilsson, P.; Boesen, T.; Vogensen, S. B.; Kromann, H.; Groth, T. Patent WO 2007 045868, 2007.

(41) Morigushi, T.; Endo, T.; Takata, T. J. Org. Chem. 1995, 60, 3523. 